Keywords: DWPF, frit, sump, slurry, solids

Retention: Permanent

\title{
DWPF Decon Frit: Sump and Slurry Solids Analysis
}

\author{
C.L. Crawford \\ D.K. Peeler \\ J.H. Gillam, Jr. \\ D.R. Click
}

October 2010

Savannah River National Laboratory Savannah River Nuclear Solutions Aiken, SC 29808

Prepared for the U.S. Department of Energy under contract number DE-AC09-08SR22470.

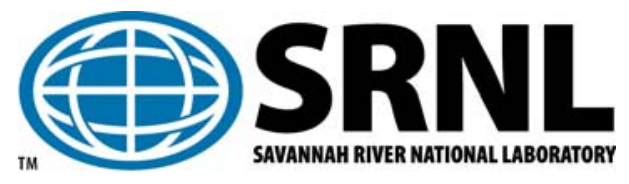




\section{DISCLAIMER}

This work was prepared under an agreement with and funded by the U.S. Government. Neither the U.S. Government or its employees, nor any of its contractors, subcontractors or their employees, makes any express or implied:

1. warranty or assumes any legal liability for the accuracy, completeness, or for the use or results of such use of any information, product, or process disclosed; or

2. representation that such use or results of such use would not infringe privately owned rights; or

3. endorsement or recommendation of any specifically identified commercial product, process, or service.

Any views and opinions of authors expressed in this work do not necessarily state or reflect those of the United States Government, or its contractors, or subcontractors.

Printed in the United States of America

Prepared for

U.S. Department of Energy 


\section{REVIEWS AND APPROVALS}

\section{AUTHORS:}

C.L. Crawford, Process Technology Programs

Date

D.K. Peeler, Process Technology Programs

Date

D.R. Click, Analytical Development

Date

\section{TECHNICAL REVIEW:}

J.M. Pareizs, Process Technology Programs

Date

APPROVALS:

C.C. Herman, Manager

Date

Process Technology Programs

S.L. Marra, Manager

Date

Environmental \& Chemical Process Technology Research Programs

J.E. Occhipinti, Manager

Date

Waste Solidification Engineering 


\section{ACKNOWLEDGEMENTS}

The authors would like to thank Dale Hutsell and Jonathan Bricker of SRR for their guidance on input on this task; John Pareizs for his thorough technical review, Sherry Vissage and Debbie Marsh for their support in the laboratory on sample preparation and analytical submittals; David Mitchell, Shirley Brunsen-Brown, and Sammie McDuffie for the coordination of technician support; and Connie Herman for management support. The authors also acknowledge the support of SRNL's Analytical Development team (technicians, researchers, and management). 


\section{EXECUTIVE SUMMARY}

The Savannah River National Laboratory (SRNL) has been requested to perform analyses on samples of the Defense Waste Processing Facility (DWPF) decon frit slurry (i.e., supernate samples and sump solid samples). Four 1-L liquid slurry samples were provided to SRNL by Savannah River Remediation (SRR) from the 'front-end' decon activities. Additionally, two 1-L sump solids samples were provided to SRNL for compositional and physical analysis.

In this report, the physical and chemical characterization results of the slurry solids and sump solids are reported. Crawford et al. (2010) provide the results of the supernate analysis. The results of the sump solids are reported on a mass basis given the samples were essentially dry upon receipt. The results of the slurry solids were converted to a volume basis given approximately 2.4 grams of slurry solids were obtained from the $\sim 4$ liters of liquid slurry sample.

Although there were slight differences in the analytical results between the sump solids and slurry solids the following general summary statements can be made. Slight differences in the results are also captured for specific analysis.

\section{Physical characterization}

$>\mathrm{SEM} / \mathrm{EDS}$ analysis suggested that the samples were enriched in Li and $\mathrm{Si}$ (B and $\mathrm{Na}$ not detectable using the current EDS system) which is consistent with two of the four principle oxides of Frit $418\left(\mathrm{~B}_{2} \mathrm{O}_{3}, \mathrm{Na}_{2} \mathrm{O}, \mathrm{Li}_{2} \mathrm{O}\right.$ and $\left.\mathrm{SiO}_{2}\right)$.

$>\mathrm{SEM} / \mathrm{EDS}$ analysis also identified impurities which were elementally consistent with stainless steel (i.e., $\mathrm{Fe}, \mathrm{Ni}, \mathrm{Cr}$ contamination).

$>$ XRD results indicated that the sump solids samples were amorphous which is consistent with XRD results expected for a Frit 418 based sample.

$>$ For the sump solids, SEM/EDS analysis indicated that the particle size of the sump solids were consistent with that of an as received Frit 418 sample from a current DWPF vendor.

$>$ For the slurry solids, SEM/EDS analysis indicated that the particle size range of the slurry solids was much broader than compared to the sump solids. More specifically, there were significantly more fines in the slurry solids as compared to the sump solids.

$>$ PSD results indicated that $>99 \%$ of both the sump and slurry solids were less than 350 microns. The PSD results also supported SEM/EDS analysis that there were significantly more fines in the slurry solids as compared to the sump solids.

\section{Weight Percent Solids}

$>$ Based on the measured supernate density and mass of insoluble solids (2.388 grams) filtered from the four liters of liquid slurry samples, the weight percent insoluble solids was estimated to be $0.060 \mathrm{wt} \%$. This level of insoluble solids is higher than the ETP WAC limit of $100 \mathrm{mg} / \mathrm{L}$, or $0.01 \mathrm{wt} \%$ which suggests a separation technology of some type would be required.

\section{Chemical Analysis}

$>$ Elemental results from ICP-ES analysis indicated that the sump solids and slurry were very consistent with the nominal composition of Frit 418 . There were other elements identified by ICP analysis which were either consistent with the presence of stainless steel (as identified by SEM/EDS analysis) or impurities that have been observed in "as received" Frit 418 from the vendor. 
$>$ IC anion analysis of the sump solids and slurry solids indicated all of the species were less than detection limits.

$>$ Radionuclide analysis of the sump solids also indicated that most of the analytes were either at or below the detection limits.

$>$ Organic analysis of the sump solids and slurry solids indicated all of the species were less than detection limits.

It should be noted that the results of this study may not be representative of future decon frit solutions or sump/slurry solids samples. Therefore, future DWPF decisions regarding the possible disposal pathways for either the aqueous or solid portions of the Decon Frit system need to factor in the potential differences. More specifically, introduction of a different frit or changes to other DWPF flowsheet unit operations (e.g., different sludge batch or coupling with other process streams) may impact not only the results but also the conclusions regarding acceptability with respect to the ETF WAC limits or other alternative disposal options. 


\section{TABLE OF CONTENTS}

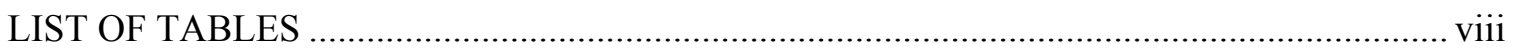

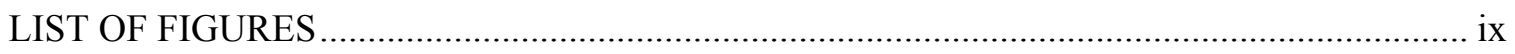

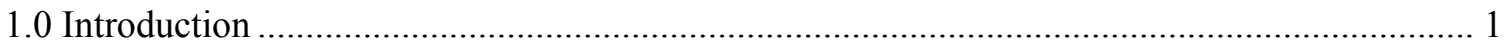

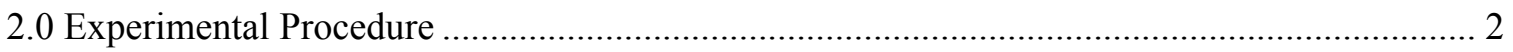

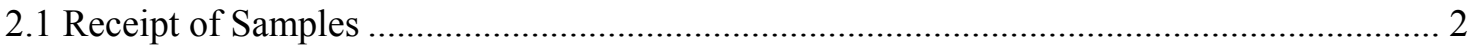

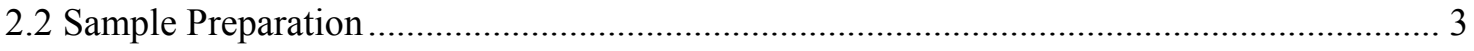

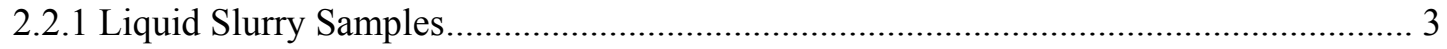

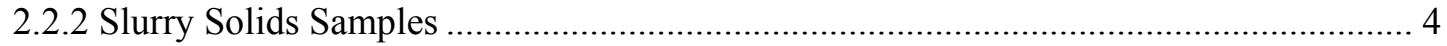

1.1.1.1 Estimated Weight Percent Solids ........................................................................... 5

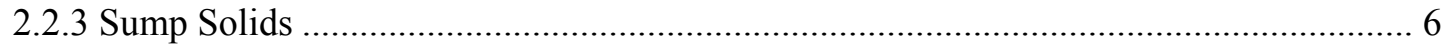

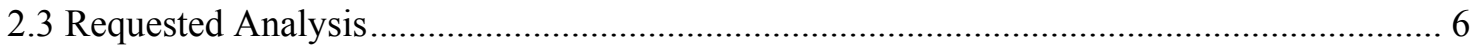

3.0 Results and Discussion: Sump and Slurry Solids Samples .................................................... 7

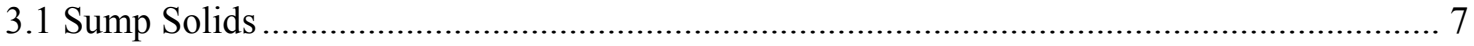

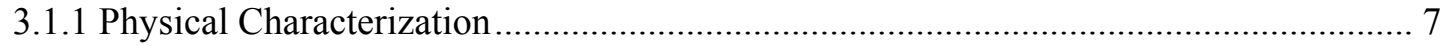

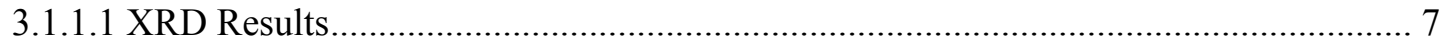

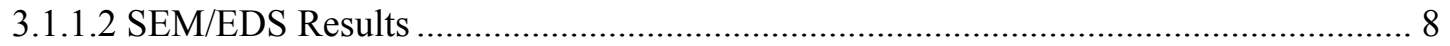

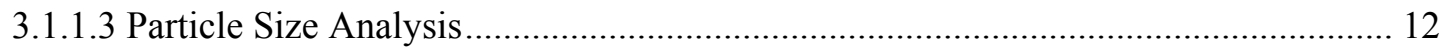

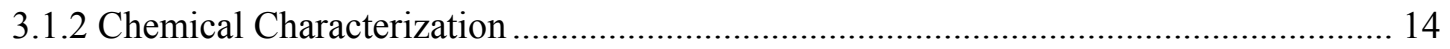

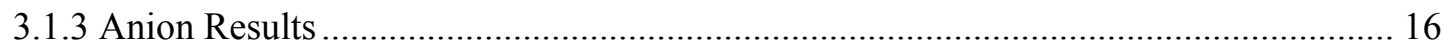

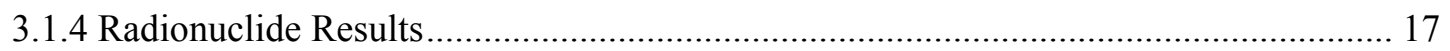

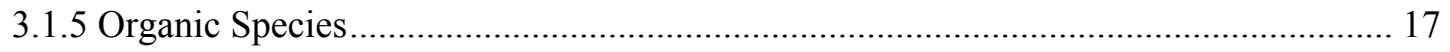

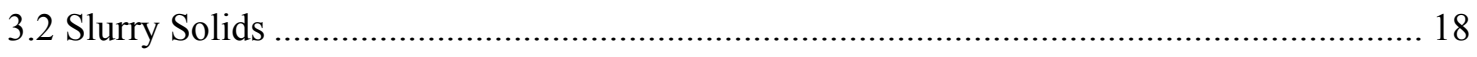

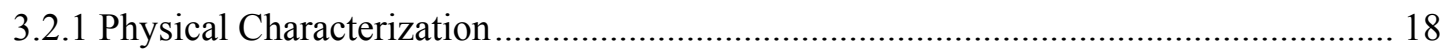

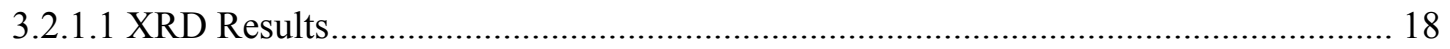

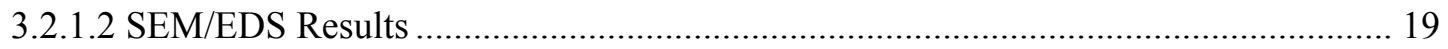

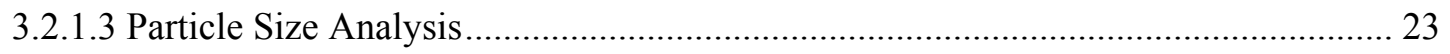

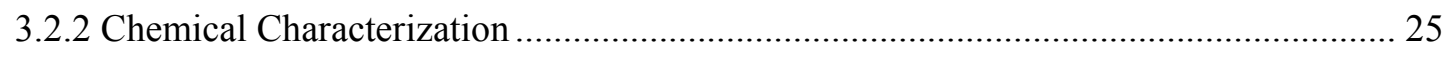

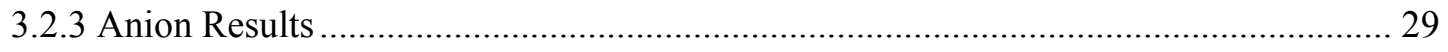

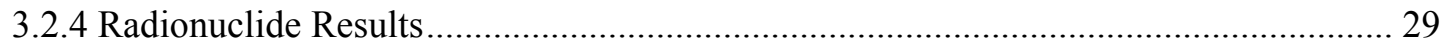

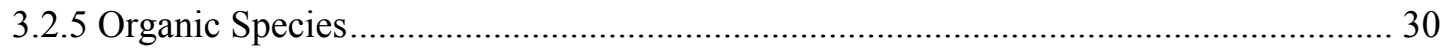

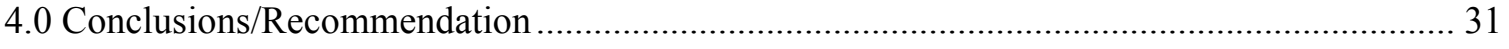

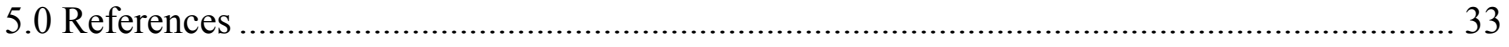




\section{LIST OF TABLES}

Table 1. Elemental Results for the Sump Solids (calcined, elemental wt \% basis). ..................... 15

Table 2. Compositional Comparison of the Sump Solids and Nominal Frit 418 (Oxide Basis).. 16

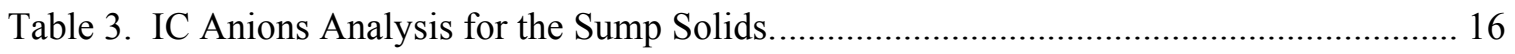

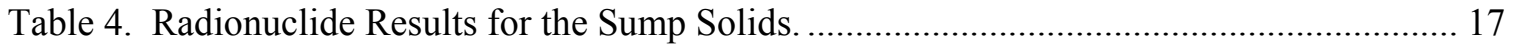

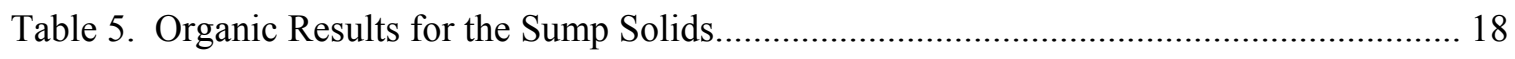

Table 6. Elemental Results for the Slurry Solids (calcined, elemental wt\%)............................. 26

Table 7. Comparison of the Slurry Solids and Nominal Frit 418 Composition (Oxide Basis).... 27

Table 8. Elemental Results for the Slurry Solids (volume basis; $\mathrm{mg} / \mathrm{mL}$ ) . ............................... 28

Table 9. IC Anions for the Slurry Solids (Mass and Volume Basis) ........................................... 29

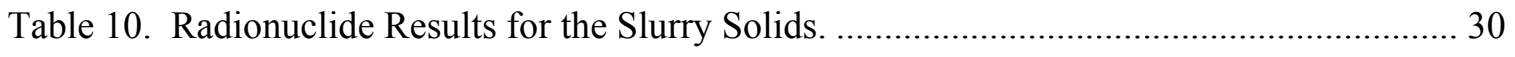

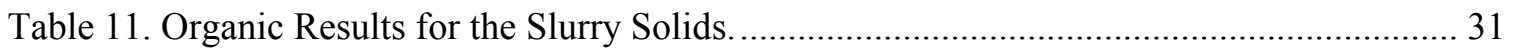




\section{LIST OF FIGURES}

Figure 1. Examples of “As Received” Liquid Slurry Samples.................................................... 2

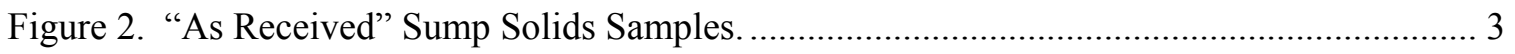

Figure 3. Liquid Slurry Sample After 3 Days of Settling......................................................... 4

Figure 4. Filtration of the Liquid Slurry Samples with Dispersed Solids (top) and Clear Filtrate

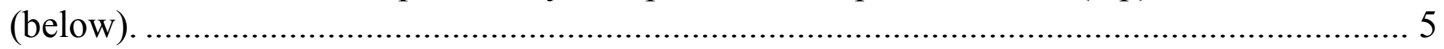

Figure 5. Filtered Solids from the Liquid Slurry Samples (Bottles \#1-\#4).................................. 5

Figure 6. Sump Solids Transferred to Weigh Pan (Prior to Air-Drying) ....................................... 6

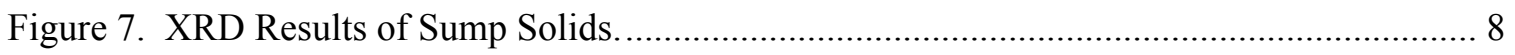

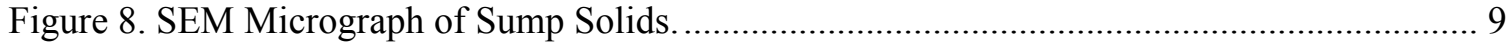

Figure 9. SEM Micrograph of Frit 418 (as received from vendor) …......................................... 9

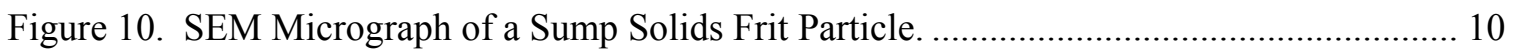

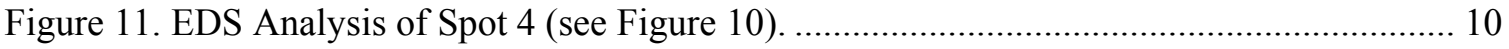

Figure 12. SEM Micrograph (higher magnification) of Sump Solids Showing Impurities. ........ 11

Figure 13. EDS Analysis of Impurities (Spot 1) in Sump Solids.............................................. 11

Figure 14. Particle Size Distribution Results of the Sump Solids.............................................. 13

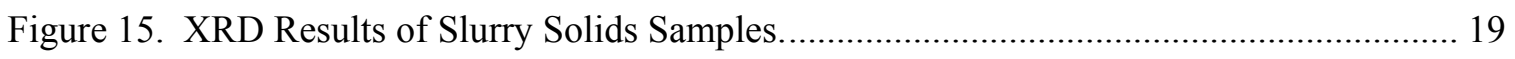

Figure 16. SEM Micrograph of Slurry Solids Sample. ............................................................. 20

Figure 17. SEM Micrograph of Frit 418 (as received from vendor). ......................................... 20

Figure 18. SEM Micrograph of Various Slurry Solids Frit Particles. ….................................... 21

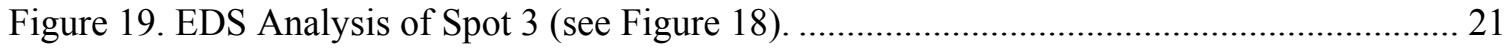

Figure 20. SEM Micrograph (higher magnification) of Sump Solids Showing Impurities. ........ 22

Figure 21. EDS Analysis of Spot 1 of Figure 20 (Slurry Solids).............................................. 22

Figure 22. EDS Analysis of Spot \#2 of Figure 20 (Slurry Solids)........................................... 23

Figure 23. Particle Size Distribution Results of the Sump Solids.............................................. 24 


\section{LIST OF ABBREVIATIONS}

\begin{tabular}{ll} 
AA & Atomic Absorption \\
AD & Analytical Development \\
CV & Cold Vapor \\
DWPF & Defense Waste Processing Facility \\
EDS & Energy Dispersive Spectroscopy \\
ETP & Effluent Treatment Plant \\
ICP-AES & Inductively Coupled Plasma - Atomic Emission Spectroscopy \\
IC & Ion Chromatography \\
MA & Mixed Acid \\
PF & Peroxide Fusion \\
PSD & Particle Size Distribution \\
RCG & Radiation Control Guide \\
RSD & Relative Standard Deviation \\
SEM & Scanning Electron Microscopy \\
SLUSOL & Slurry Solids \\
SME & Slurry Mix Evaporator \\
SRNL & Savannah River National Laboratory \\
SRR & Savannah River Remediation \\
STDEV & Standard Deviation \\
SVOA & Semi-Volatile Organic Analysis \\
SUMPSOL & Sump Solids \\
TTR & Task Technical Request \\
TTQAP & Task Technical and Quality Assurance Plan \\
VOA & Volatile Organic Analysis \\
WAC & Waste Acceptance Criteria \\
WWCT & Waste Water Collection Tank \\
XRD & X-Ray Diffraction \\
& \\
\hline
\end{tabular}




\subsection{Introduction}

The Defense Waste Processing Facility (DWPF) process improvement commitments for the current Savannah River Remediation (SRR) contract include the implementation of a water separation technology to separate the frit solids from the decon frit slurry transferred from the canister decontamination system to the Slurry Mix Evaporator (SME). Currently, all of the spent frit slurry from the canister decontamination process, which contains approximately $98 \%$ water by volume, is transferred to the SME resulting in additional cycle time associated with boiling off the water, as well as significant burden on the DWPF recycle waste system. The current process produces a 'front-end' frit slurry as well as a rinse/flush dilute solution. The combined volume of these processes is $\sim 800-1,000$ gallons per canister. It is proposed that a water separation technology be utilized to minimize the amount of water being sent to the SME which should alleviate the SME boil-down times (i.e., "dry" decontamination frit additions to the SME are the goal). Generically, the underflow (solids) will still be transferred to the SME, and the overflow (liquid) will be transferred to the Effluent Treatment Plant (ETP) or an alternate treatment facility. Since the spent frit slurry also contains the oxide layer removed from the stainless steel canister surface during the decontamination process (estimated to be $70 \mathrm{~g}$ of material in 800 gallons of slurry (Hutsell 2010), and the overflow (liquid) stream may still contain traces of contaminated frit, it is unknown whether or not the overflow would be acceptable for transfer to ETP or an alternate treatment facility.

The Savannah River National Laboratory (SRNL) has been requested to perform analyses on samples of the decon frit slurry (i.e., supernate samples and sump solid samples) as defined by Hutsell (2010). Four 1-L liquid slurry samples were provided to SRNL by SRR from the 'frontend' decon activities. Additionally, two 1-L sump solids samples were provided to SRNL for compositional and physical analysis. Hutsell (2010) also indicated that even though the asreceived decon frit slurry samples will represent a bounding case with respect to meeting the ETP Waste Acceptance Criteria (WAC) requirements, a sample of the supernate (after settling of the as-received samples) should also be taken and analyzed. The supernate sample is expected to more closely mimic the overflow stream (liquid) and should provide a more realistic representation of the waste stream proposed to be transferred to ETP or an alternate treatment facility.

In response to the SRR request, Crawford and Peeler (2010) provided a Task Technical and Quality Assurance Plan (TTQAP) with an outline of the sample preparation techniques, task responsibilities spanning the various organizations associated with the task, a high-level overview of the task, and a detailed analytical study plan with corresponding sample and analytical controls to be used.

In this report, the results of the sump and slurry solids are reported. The results of the supernate (samples decanted from the liquid slurry samples received from SRR after settling for $\sim 3$ days) have been reported by Crawford et al. (2010). 


\subsection{Experimental Procedure}

Prior to a discussion of the sump and slurry solids analytical results, a general description of the "as received" samples and the protocols used to generate the supernate, sump solids, and slurry solids samples are fully described in this section. Information regarding the sample preparation, analytical requests, and results can be found in WSRC-NB-99-00002 and SRNL-NB-2010-00033. As previously mentioned, the results of the supernate samples have been reported by Crawford et al. (2010) with the current report focusing on the analytical results from the sump and slurry solids.

\subsection{Receipt of Samples}

On June 8, 2010, SRNL received six 1-L polybottles from SRR. Four 1-L bottles (labeled \#1 through \#4) contained the liquid slurry samples. The contents were generally described or classified as "clear" with a small amount of visible solids on the bottom. Figure 1 shows examples of two of the four liquid slurry bottles. (Note these photos were taken after Bottles \#1 and $\# 2$ were composited, redistributed into two 1-L bottles, and allowed to settle for $\sim 3$ days).

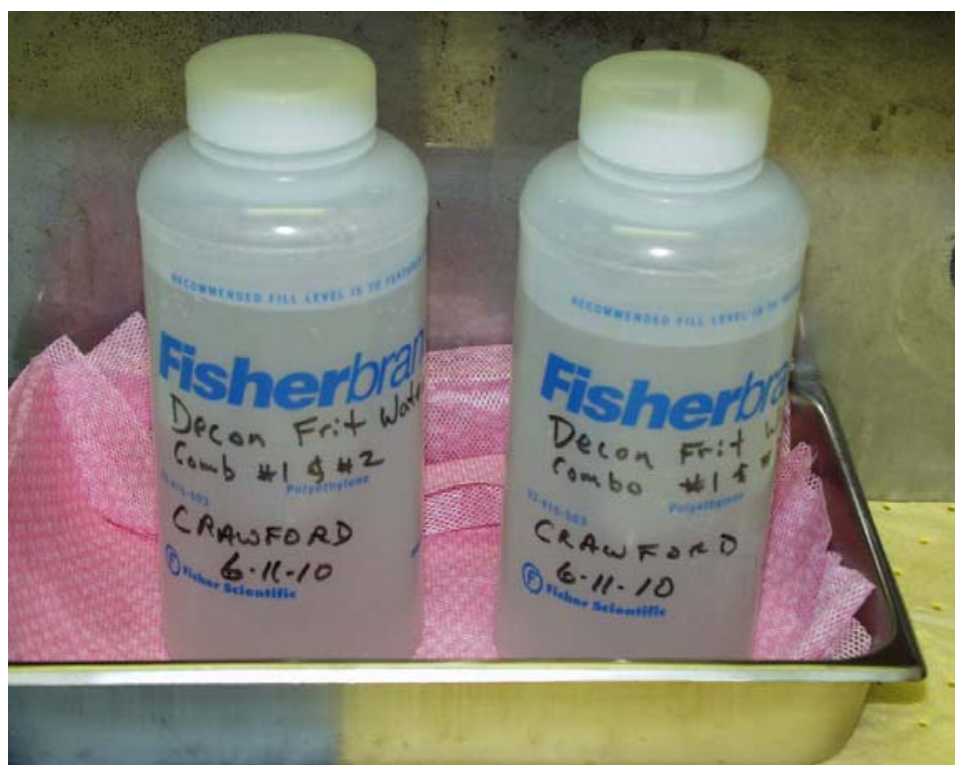

Figure 1. Examples of "As Received” Liquid Slurry Samples.

(after Bottles \#1 and \#2 were composited and allowed to settle for $\sim 3$ days).

Two of the six 1-L bottles received from SRR contained sump solids. These bottles contained primarily solids (e.g., frit) and had a small but visible clear liquid layer on the top of the solids. These two bottles were labeled \#5 and \#6 and are shown in Figure 2. 


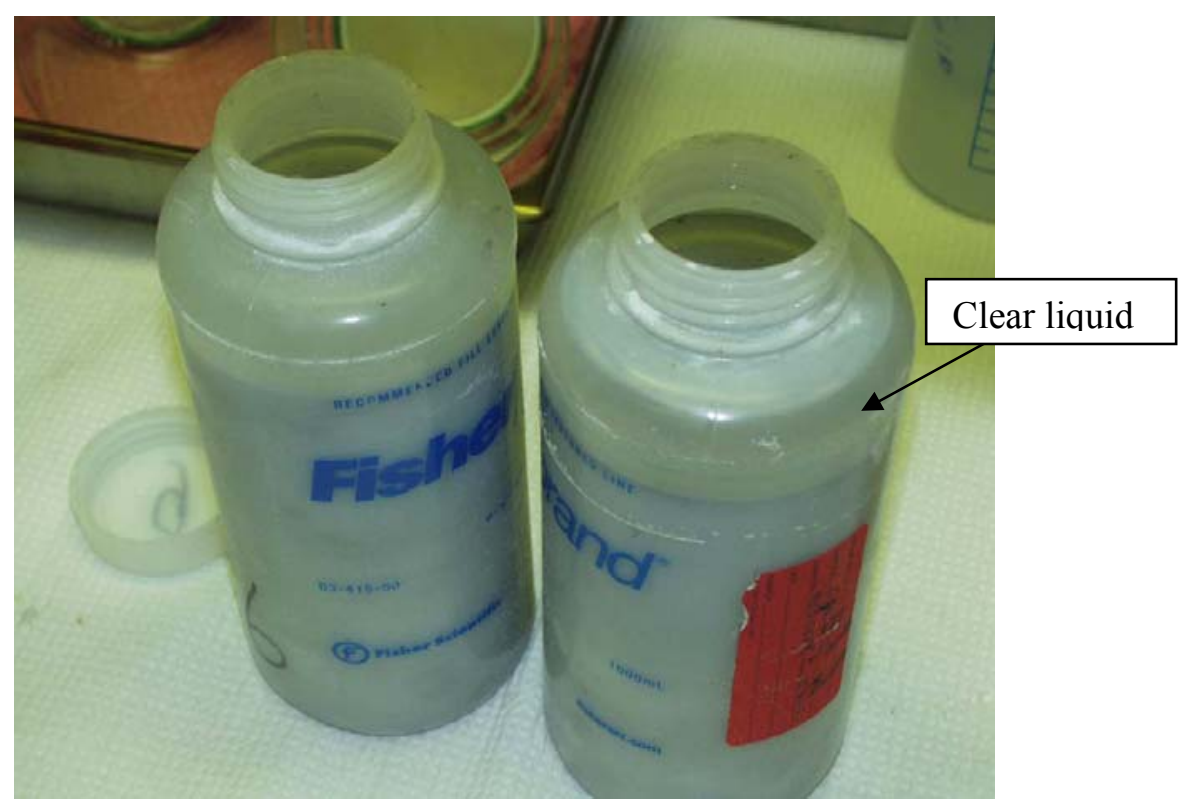

Figure 2. “As Received” Sump Solids Samples.

(Note clear liquid fraction on top of the solids)

\section{2 $\underline{\text { Sample Preparation }}$}

Based on dose readings $(<1 \mathrm{mrem} / \mathrm{hr})$, sample preparation and handling of all of the frit decon samples (both solids and liquids) could be performed in a radiochemical hood. The following sections describe the sample preparation process that was used to produce the supernate, slurry solids, and sump solids samples ultimately submitted to Analytical Development (AD).

\subsubsection{Liquid Slurry Samples}

Two of the four liquid slurry samples (Bottles \#1 and \#2) were combined and then reallocated into separated 1-L polybottles and allowed to settle over an approximate 3 day period. Figure 3 shows one of the liquid slurry samples after 3 days of settling. Note the visible solids on the bottom of the polybottle. To obtain the supernate fraction of these samples, a pipette was used to transfer most of the liquid from each bottle working from top to bottom to minimize the potential for any of the settled solids from being transferred. (These samples were not filtered - only transferred with a pipette into a separate polybottle). The results from the supernate analyses have been previously reported (Crawford et al. 2010) and compared to the ETP WAC requirements as defined by Martin (2009), Revision 4. 


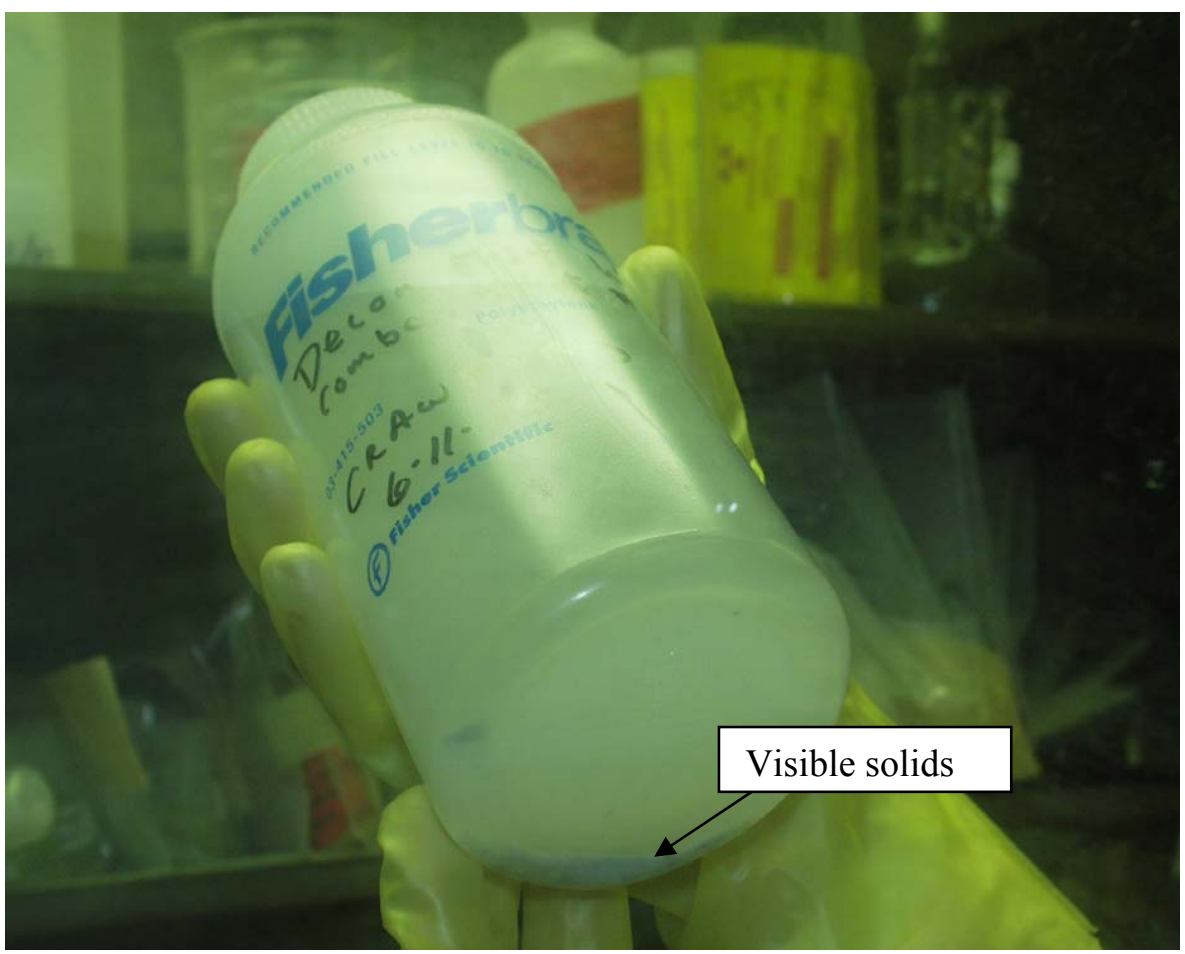

Figure 3. Liquid Slurry Sample After 3 Days of Settling.

(Note solids settled on bottom of polybottle)

\subsubsection{Slurry Solids Samples}

The two remaining "as received" liquid slurry bottles (\#3 and \#4) were combined with the remaining liquid and trace solids from Bottles \#1 and \#2 (those used to generate the supernate samples as noted in Section 2.2.1). The liquid-solid sample was slurried and then filtered (using a 0.2 or 0.45 micron filter) to obtain the insoluble solids from the liquid slurry Bottles \#1 through \#4.

Figure 4 shows the dispersed solids (top portion) and clear filtrate (below) during the filtration process. The solids (from Bottle \#1 - Bottle \#4) were collected on 3 filters - see Figure 5. The two leftmost filters were collected on 6/30/10 and air-dried overnight. The last filter (right) was collected on the day the photo was taken (7/1/10) and appears darker in color due to moisture content in the filter. All of the solids were continuously air-dried until 7/5/10. At that point, the solids were combined and four samples were obtained (labeled as SLUSOL-1, SLUSOL-2, SLUSOL-3, and SLUSOL-4) ${ }^{\mathrm{a}}$ to support the required chemical analyses. Additional samples were taken to support the physical analysis (i.e., particle size (PSD), x-ray diffraction (XRD), and scanning electron microscopy (SEM)). These samples are referred to as the "slurry solids" throughout this report.

\footnotetext{
a "SLUSOL" referring to the slurry (slu) solids (sol) which were filtered.
} 


\subsubsection{Estimated Weight Percent Solids}

The supernate density was measured to be nominally $1.0 \mathrm{~g} / \mathrm{mL}$. As previously described, after decanting some of the supernate for the supernate analysis study, all of the remaining 4 Liters of sample were filtered through either 0.2 or 0.45 micron filters. The insoluble solids collected from filtration were air-dried and weighed to be a total of $2.388 \mathrm{~g}$. Thus the weight percent insoluble solids in the original 4 Liters (4,000 grams) can be estimated to be mass of insoluble solids divided by total mass. This calculation gives ( $2.388 \mathrm{~g}$ insoluble solid / $(2.388 \mathrm{~g}$ solids $+4,000 \mathrm{~g}$ supernate) $) * 100=0.060 \mathrm{wt} \%$ insoluble solids. This level of insoluble solids is higher than the ETP WAC limit of $100 \mathrm{mg} / \mathrm{L}$, or $0.01 \mathrm{wt} \%$.

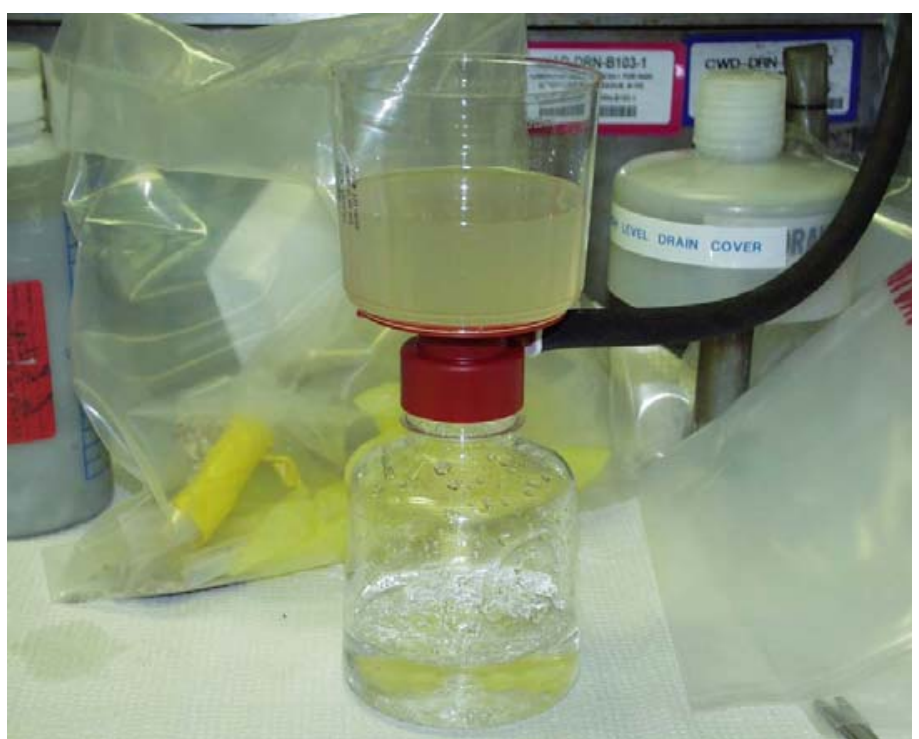

Figure 4. Filtration of the Liquid Slurry Samples with Dispersed Solids (top) and Clear Filtrate (below).

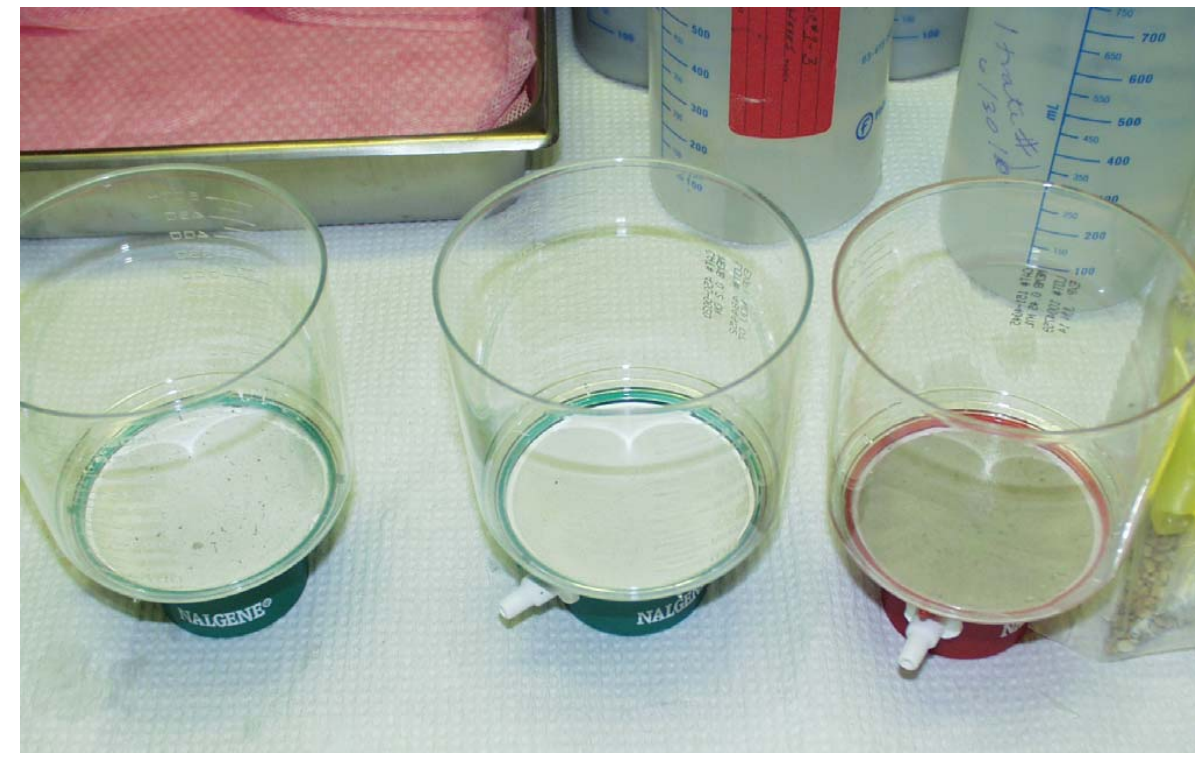

Figure 5. Filtered Solids from the Liquid Slurry Samples (Bottles \#1-\#4). 


\subsubsection{Sump Solids}

The final set of samples was obtained from the two 1-L polybottles (\#5 and \#6) containing the sump solids (refer to Figure 2 for "as received' sump solids). The water/liquid layer on the top of the solids was decanted (to remove as much of the "free" water as possible) resulting in about 250 $\mathrm{mL}$ (approximately $125 \mathrm{~mL}$ from each bottle).

After decanting, approximately 20 grams of damp/wet solids was removed from each bottle and transferred to a weigh pan yielding approximately 40 grams of sump solids (see Figure 6). The sump solids were described as being similar to beach sand. The sump solids were air-dried in a radiohood for approximately 4 days.

Four sump solid samples were obtained for AD chemical analysis (labeled as SUMPSOL-1, SUMPSOL-2, SUMPSOL-3, and SUMPSOL-4). Additional sump solids samples were taken to support the physical analysis (i.e., PSD, XRD, and SEM).

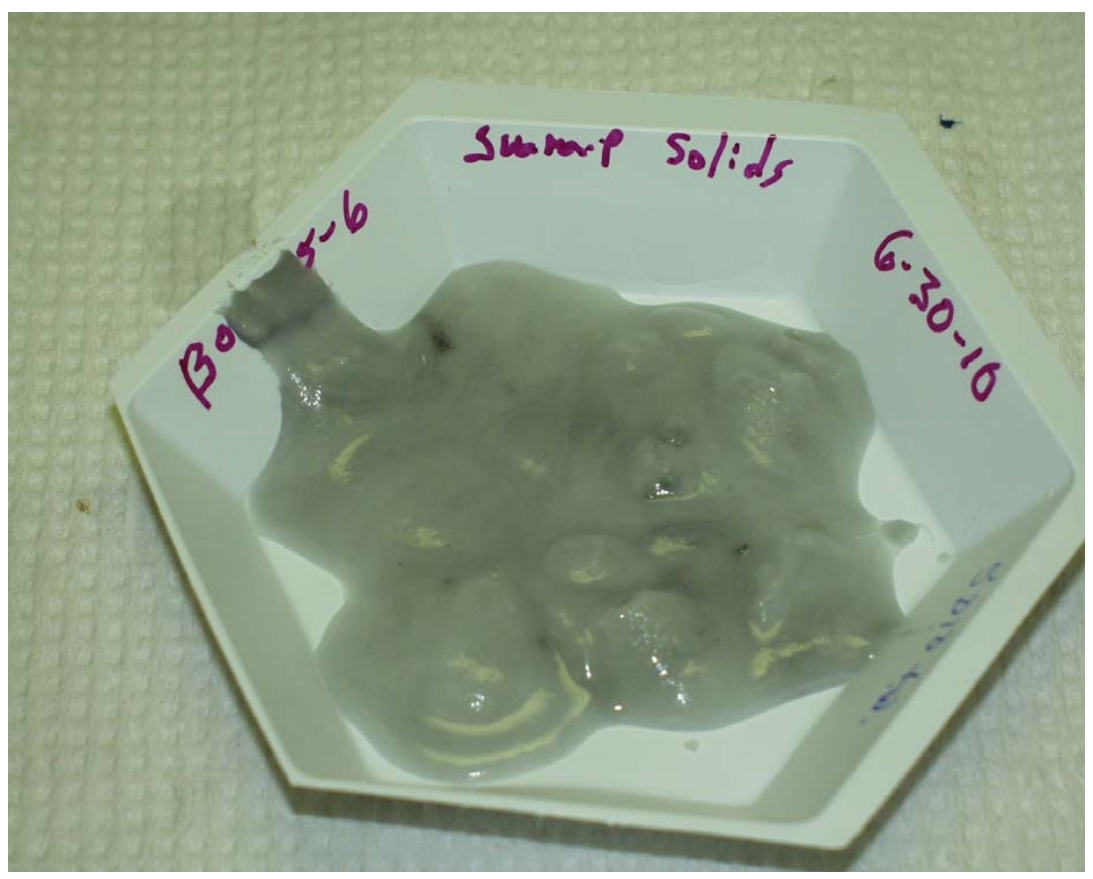

Figure 6. Sump Solids Transferred to Weigh Pan (Prior to Air-Drying).

\subsection{Requested Analysis}

The solid (slurry and sump) samples were submitted to AD for physical and chemical characterization. As specified by the Task Technical Request (TTR) (Hutsell 2010) and outlined by the TTQAP (Crawford and Peeler 2010, Revision 1), chemical and physical properties or analysis required to support programmatic objectives were:

$>$ Anions: $\mathrm{CO}_{3}^{-2}, \mathrm{Cl}^{-}, \mathrm{F}^{-}, \mathrm{NO}_{3}^{-}, \mathrm{NO}_{2}^{-}, \mathrm{C}_{2} \mathrm{O}_{4}^{-2}, \mathrm{PO}_{4}^{-3}$, and $\mathrm{SO}_{4}^{-2}$

$>$ Cation: $\mathrm{NH}_{4}^{+}$ 
$>$ Elementals (at least the following): Ag, Al, As, B, Ba, Be, Cd, Cu, Fe, $\mathrm{Hg}, \mathrm{Mn}, \mathrm{Ni}, \mathrm{Pb}$, $\mathrm{Sb}, \mathrm{Se}, \mathrm{Si}$, and $\mathrm{Zn}$

$>$ Radionuclides: total alpha, total beta/gamma, H-3, C-14, Ni-63, Co-60, Sr-90, Tc-99, Ru106, Sn-126, Sb-125, I-129, Cs-137, Eu-154, U-233, U-235, Pu-241, and Radiation Control Guide (RCG) as defined in Attachment 8.2 of X-SD-H-00009 (Martin 2009).

$>$ Volatile Organic Analysis (VOA) and Semi-Volatile Organic Analysis (SVOA)

$>$ Particle size distribution (only for slurry and sump solids)

$>\mathrm{pH}$ (only for supernate)

$>$ Weight percent solids (only for slurry solids)

Crawford and Peeler (2010) provide a synopsis of the sample preparation, types of analyses to be performed, methods/instrumentation to be used for the analysis of specific analytes, and the analytical controls implemented.

\subsection{Results and Discussion: Sump and Slurry Solids Samples}

In this section, the results of the sump and slurry solids are provided. The results (both physical and chemical characterization) are initially presented for the sump solids (see Section 3.1) followed by the results of the slurry solids (see Section 3.2). DWPF was utilizing Frit 418 to support canister decon activities when the sump/slurry solids samples were taken. Therefore, additional analysis will be presented on a sample of "as-received" Frit 418 (as-received from one of the current frit vendors) to provide a baseline for which some comparisons are made.

\subsection{Sump Solids}

In this section the results of the physical (XRD, SEM with energy dispersive spectroscopy (EDS), and PSD) and chemical characterization of the sump solids are presented and discussed. Given the sump solids were essentially dry, direct comparisons to the ETP WAC limits are not made. More specifically, the analytical results for the sump solids are reported on a mass basis and the ETP WAC limits are on a volume basis. Therefore, the sump solids data are presented to support supplemental or alternative disposal options.

\subsubsection{Physical Characterization}

\subsubsection{XRD Results}

The result of the XRD analysis of the sump solids sample is shown in Figure 7. A characteristic amorphous hump is observed with the absence of well defined peaks indicating that the sump solid sample is amorphous (or glass). The lack of well defined peaks in this XRD pattern suggests that no crystalline materials (stainless steel, crystalline impurities, etc.) were detected at the XRD detection limit. Samples were analyzed under conditions providing a detection limit of approximately $0.5 \mathrm{vol} \%$ (i.e., no crystals can be detected if the amount in the sample is less than $\sim 0.5$ vol\%). These results (amorphous hump) are consistent with expectations of a Frit 418 based sample.

\footnotetext{
${ }^{\mathrm{b}} \mathrm{C}-14$ was removed from the analysis request based on communications from J. Bricker to D. Peeler (personnel communication via email on June 23, 2010 - see WSRC-NB-2009-00002, page 44 for more details). Also the RCG value was not calculated for the sump solids given the difference in mass (sump solids) versus volume (RCG) basis.
} 


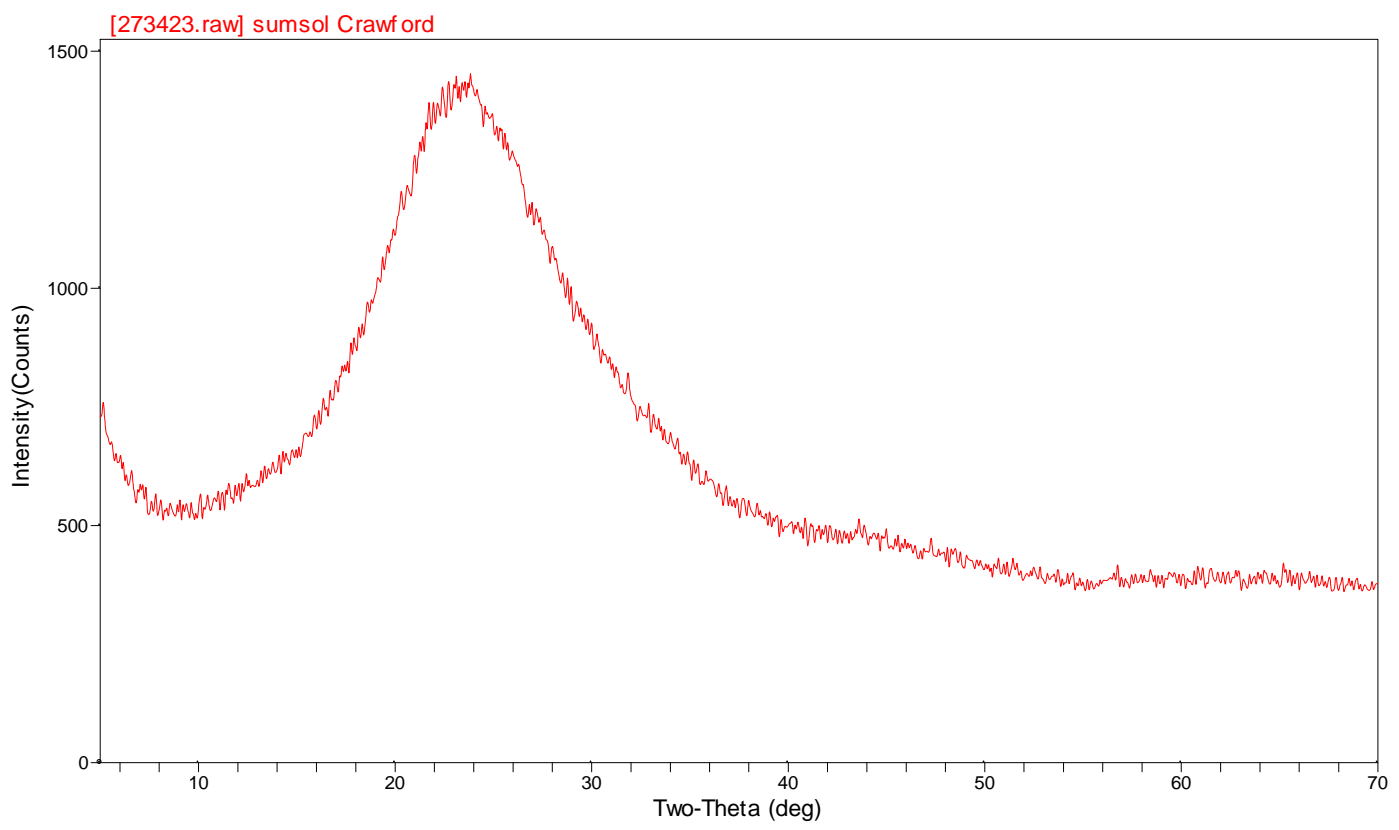

Figure 7. XRD Results of Sump Solids.

\subsubsection{SEM/EDS Results}

Figure 8 provides a low magnification $(17 x)$ micrograph of the sump solids. Figure 9 shows a SEM micrograph (at the same magnification) of Frit 418 as received from a vendor. A comparison of the two figures shows very little (if any) difference between the sump solids and as received Frit 418 with respect to particle size.

Figures 10 and 11 provide a closer view of a sump solids frit particle and the corresponding $\mathrm{SEM} / \mathrm{EDS}$ analysis, respectively. The SEM/EDS analysis (Figure 11) indicates that $\mathrm{Na}$ and $\mathrm{Si}$ are present in this particle. The nominal composition of Frit 418 is $8 \mathrm{wt} \% \mathrm{~B}_{2} \mathrm{O}_{3}, 8 \mathrm{wt} \% \mathrm{Li}_{2} \mathrm{O}, 8 \mathrm{wt} \%$ $\mathrm{Na}_{2} \mathrm{O}$, and $76 \mathrm{wt} \% \mathrm{SiO}_{2}$. The EDS detector is unable to detect the presence of $\mathrm{Li}$ and/or $\mathrm{B}$. The presence of $\mathrm{Na}$ and $\mathrm{Si}$ in Figure 11 provides some indication that this is Frit 418 (although quantitative information can not be easily surmised from the EDS analysis).

Figure 12 provides a higher magnification micrograph of the sump solids. In this figure, "impurities" are observed (as denoted by the presence of bright spots on the surface of several frit particles). Bright spots in SEM analysis are the result of the presence of a higher atomic numbered element(s) as compared to the darker regions of the micrograph. The EDS analysis of these impurities (also labeled as Spot 1 by AD) indicates that these spots contain $\mathrm{Fe}, \mathrm{Ni}$, and $\mathrm{Cr}$. The presence of these components suggests the presence of stainless steel in the sump solids sample from the canister decon process. Although not shown in this report, SEM/EDS analysis of the sump solid sample also identified Co and Mn (possible from stainless steel) as well as Mo. ${ }^{\mathrm{c}}$

\footnotetext{
${ }^{c}$ For detailed information on the SEM/EDS analysis of the sump solids, refer to WSRC-NB-99-00002, pages 56 through 64.
} 


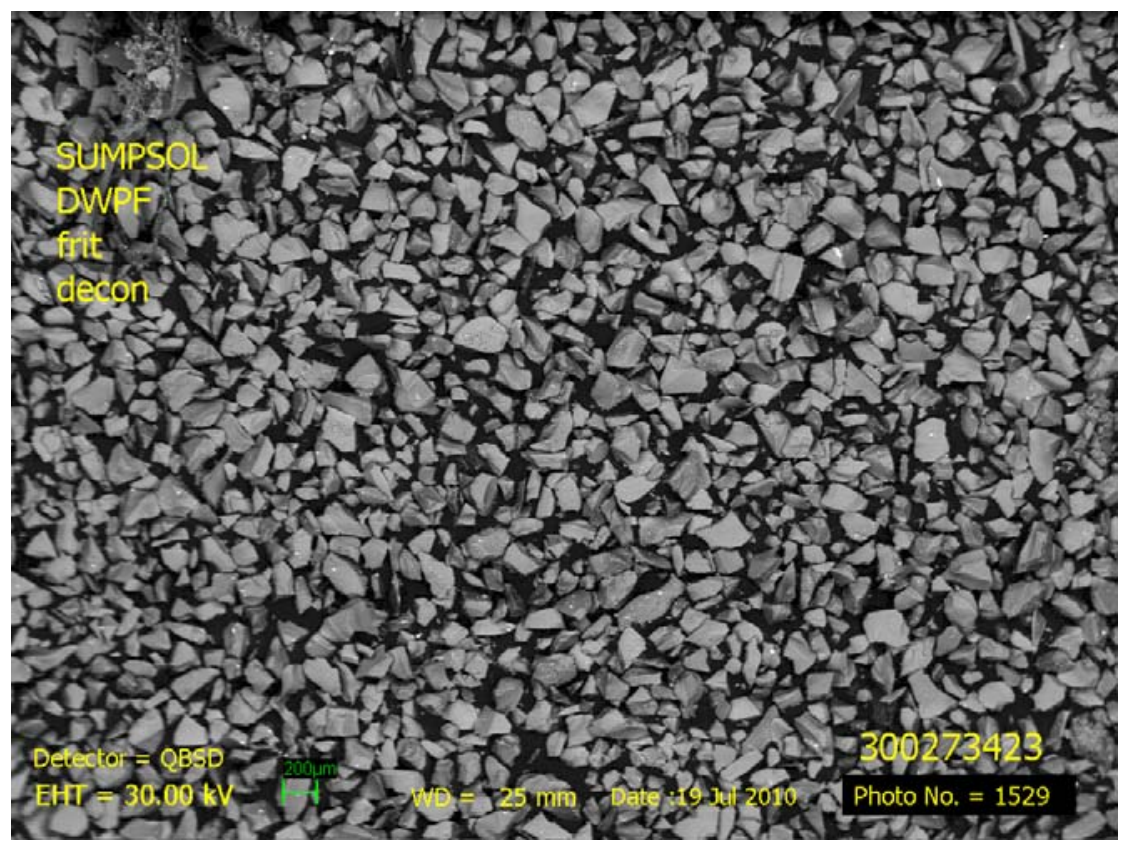

Figure 8. SEM Micrograph of Sump Solids.

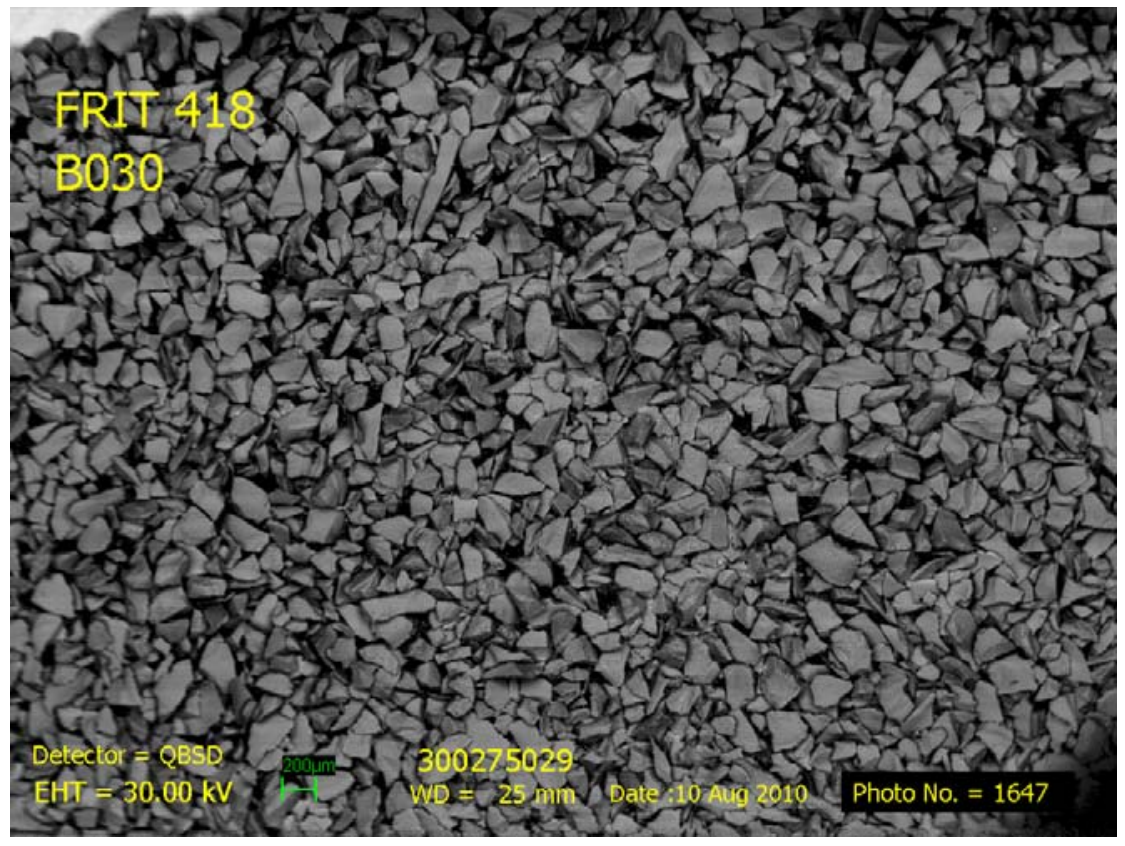

Figure 9. SEM Micrograph of Frit 418 (as received from vendor) 


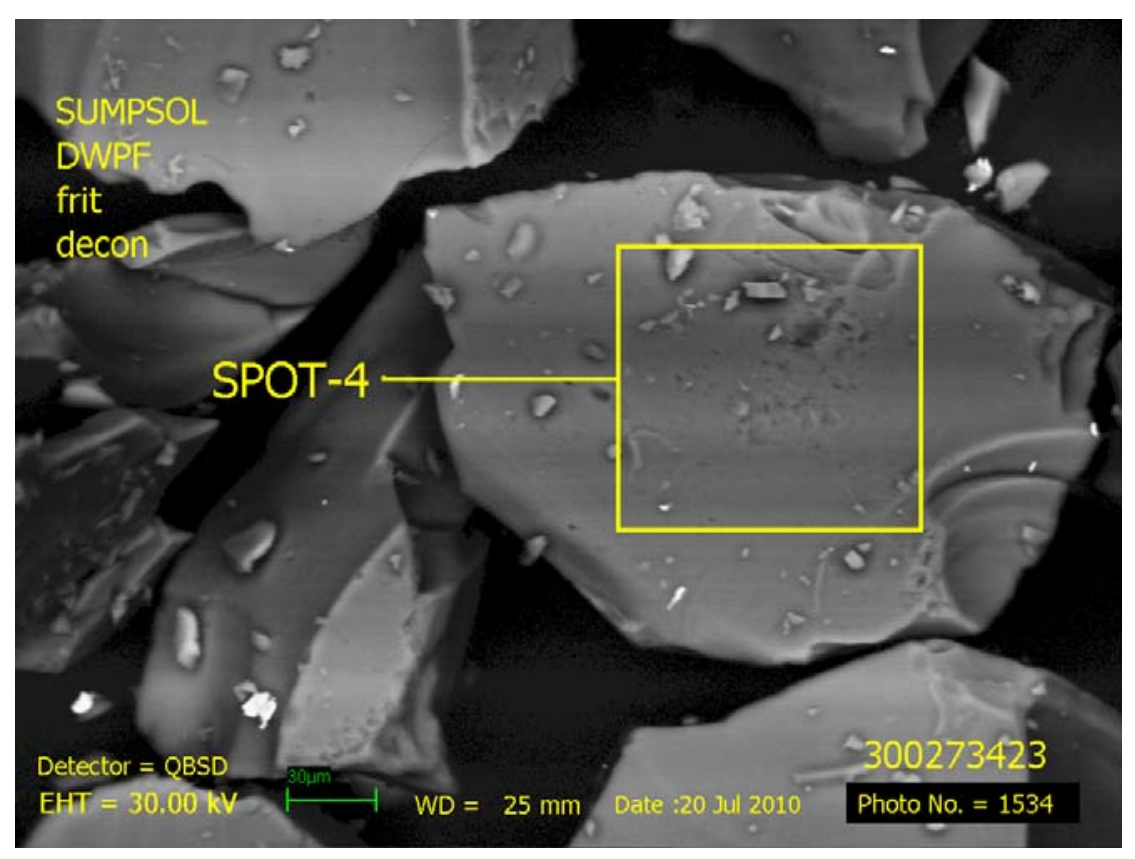

Figure 10. SEM Micrograph of a Sump Solids Frit Particle.

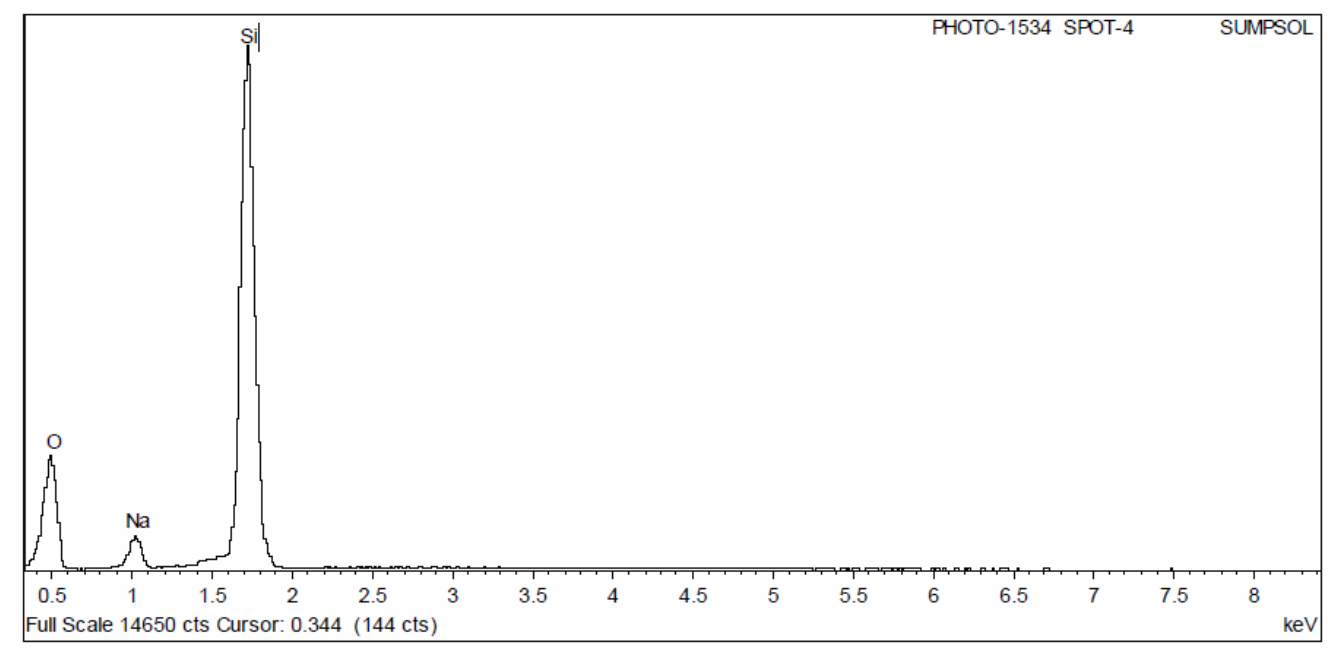

Figure 11. EDS Analysis of Spot 4 (see Figure 10). 


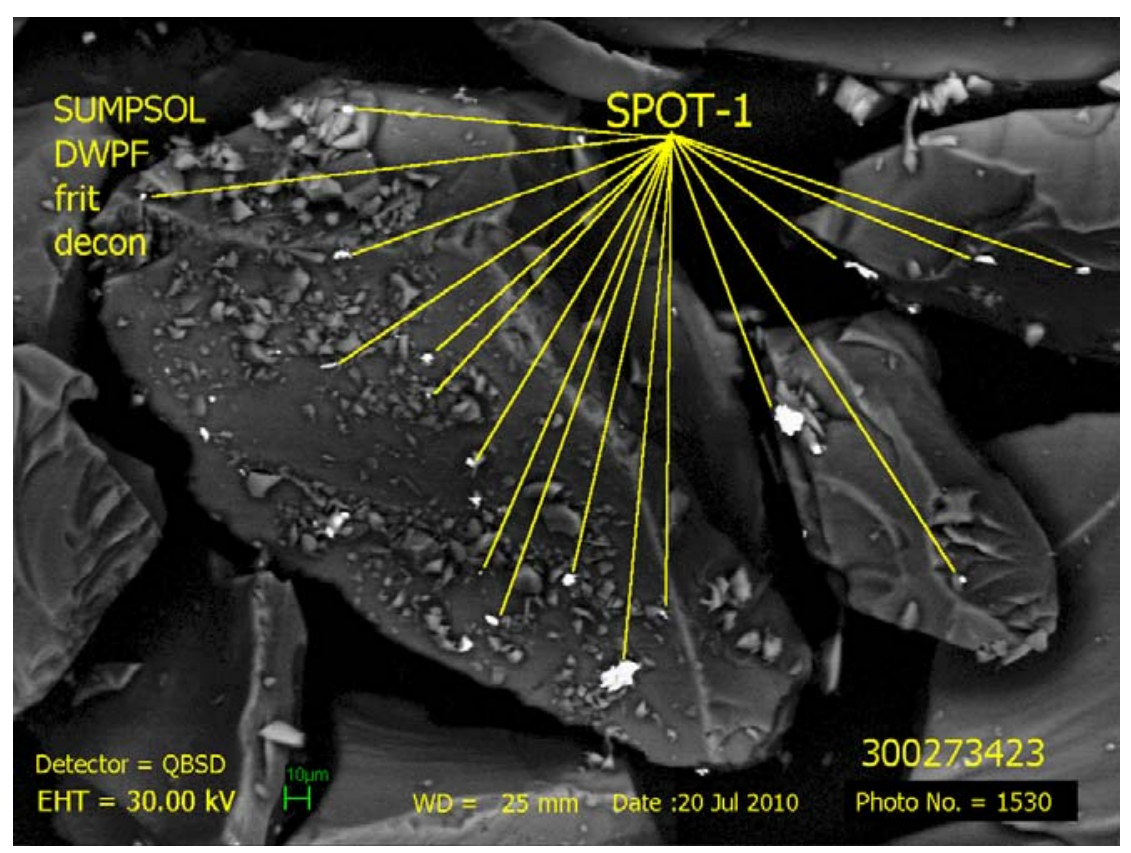

Figure 12. SEM Micrograph (higher magnification) of Sump Solids Showing Impurities.

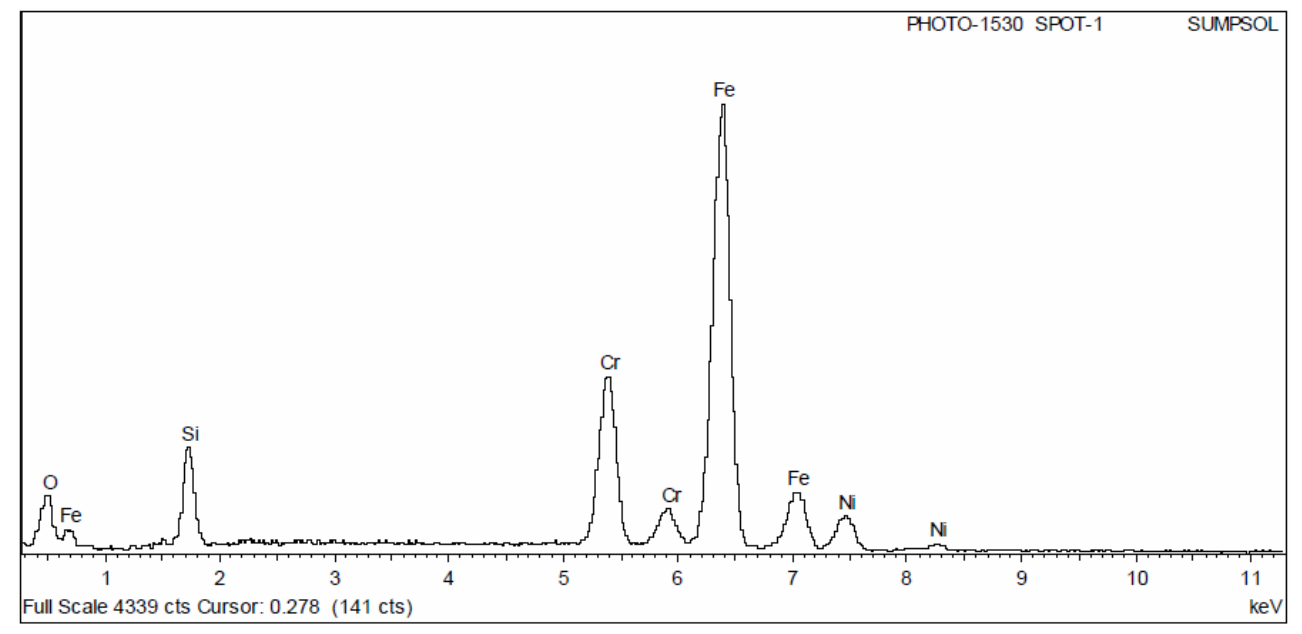

Figure 13. EDS Analysis of Impurities (Spot 1) in Sump Solids. 
Figure 14 provides the PSD results of the sump solids. In this method, particles are added to a liquid (typically reagent water) to form a dilute solution/suspension. This solution is pumped through a transparent sample cell. Low angle, forward-scattered light from a diode laser is projected through a stream of particles. As light rays strike the particles, they are scattered through angles which are inversely proportional to their sizes. A photodiode array measures the quantity of light at several pre-determined angles. Electrical signals proportional to the measured light flux values are then computer processed to form a multi-channel histogram of the particle size distribution. Microtrac particle size analyzers measure particle size distribution in terms of the volume of particles. An equivalent spherical diameter can then be calculated. Particles from 1408 microns to 0.243 microns can be measured by this method. Based on these results, approximately $99.3 \%$ of the particles are less than 350 microns. 
MICEROTRAC: - XTOO

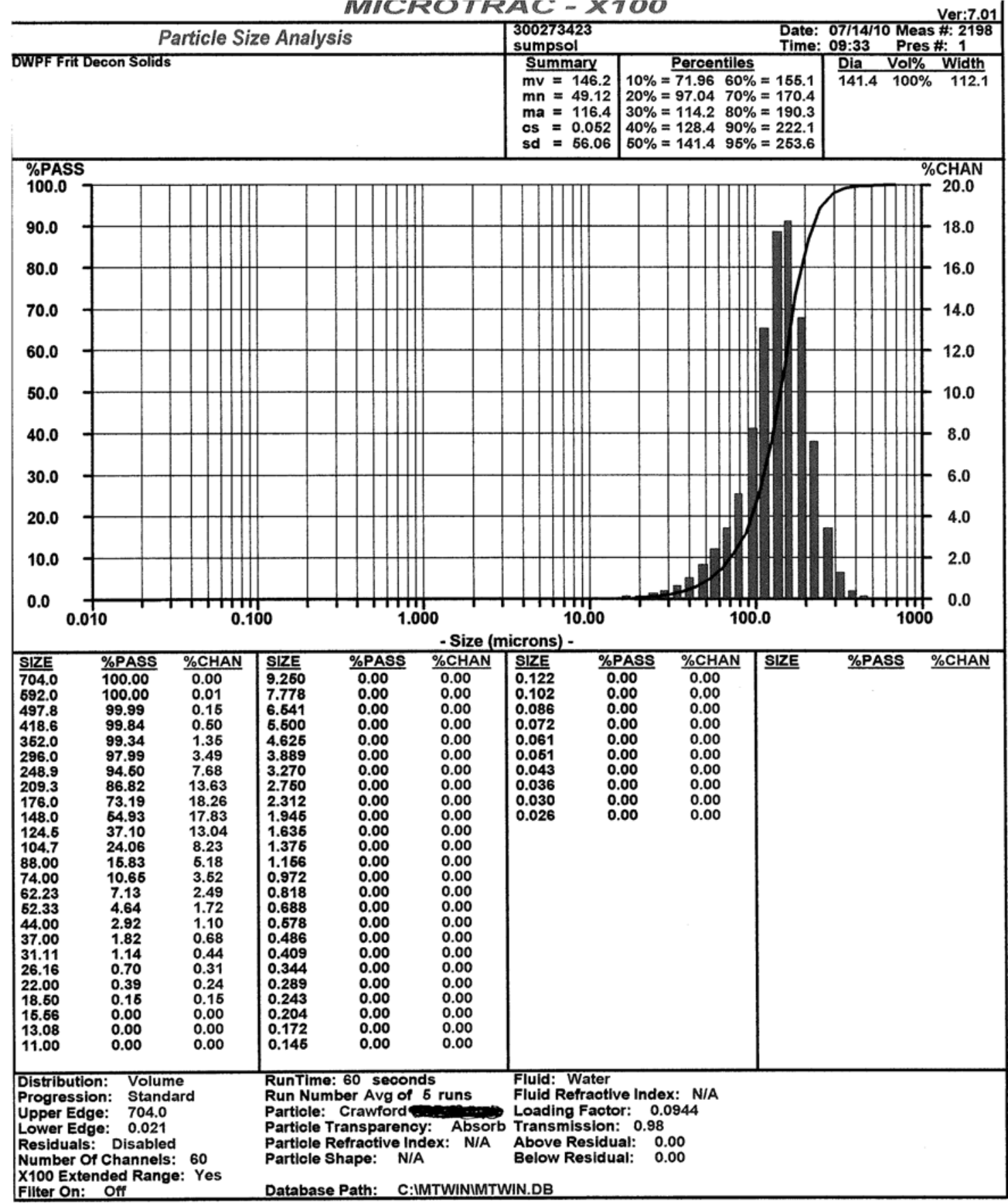

Figure 14. Particle Size Distribution Results of the Sump Solids. 


\subsubsection{Chemical Characterization}

To support compositional analysis of the sump solids, four representative samples were provided to AD. The samples were dissolved using both peroxide fusion (PF) and mixed acid (MA) techniques. The solutions were then analyzed by Inductively Coupled Plasma (ICP) Atomic Emission Spectroscopy (AES) or Atomic Absorption (AA). The averaged results of the quadruplicate analysis are shown in Table 1 (calcined elemental wt\%). Also shown in Table 1 are the specific digestion method (PF and/or MA) and analytical technique that were used to compute the average for each element. For example, the average aluminum (Al) concentration was computed from the four ICP-AES values resulting from the PF digestion. For iron (Fe), the averaged concentration was reported from the eight ICP-AES results ( 4 from PF and 4 from MA). The standard deviation (STDEV) and percent relative standard deviations (RSD) associated with the elemental wt\% values are also provided - when appropriate (i.e., when values were above detection limits).

Given the use of Frit 418 during DWPF processing while sampling for this task the elemental values of $\mathrm{B}, \mathrm{Li}, \mathrm{Na}$, and $\mathrm{Si}$ are highlighted in Table 1. As expected, these four components are the major contributors in the sump solids analysis. In addition to major components $(\mathrm{B}, \mathrm{Li}, \mathrm{Na}$, and $\mathrm{Si}$ ), the ICP-ES results also provide measurable concentrations for $\mathrm{Al}, \mathrm{Ba}, \mathrm{Ca}, \mathrm{Cr}, \mathrm{Fe}, \mathrm{K}, \mathrm{Mg}$, $\mathrm{Mn}, \mathrm{Mo}, \mathrm{Ni}$, Sr, Ti, and Zr. As presented in Section 3.1.1.2, SEM/EDS analysis also detected Cr, $\mathrm{Ni}$, and $\mathrm{Fe}$ (from stainless steel), Co and Mn (also possible impurities of stainless steel) and Mo. The other components ( $\mathrm{Al}, \mathrm{Ba}, \mathrm{Ca}, \mathrm{K}, \mathrm{Mg}, \mathrm{Sr}, \mathrm{Ti}$, and $\mathrm{Zr}$ ) could be impurities in the as-received frit. For example, SRNL analysis of Frit 418 Lot \#67 (from Ferro Corporation) indicated the presence of $1.05 \mathrm{wt} \% \mathrm{Al}_{2} \mathrm{O}_{3}, 0.111 \mathrm{wt} \% \mathrm{CaO}, 0.078 \mathrm{wt} \% \mathrm{Fe}_{2} \mathrm{O}_{3}, 0.056 \mathrm{wt} \% \mathrm{MgO}, 0.093 \mathrm{wt} \%$ $\mathrm{TiO}_{2}$, and $0.022 \mathrm{wt} \% \mathrm{ZrO}_{2}$ (Best 2010). Thus those elemental impurities not associated with stainless steel are probably contaminants in the as received frit.

The elemental information in Table 1 was converted to an oxide basis for a direct comparison with the nominal Frit 418 composition. Table 2 shows the measured and normalized (to $100 \%$ ) composition of the sump solids analysis as well as the nominal (or target) composition of Frit 418 . The four major oxides of Frit 418 are shaded to aid in the comparison. The measured sump solids data provide a sum of oxides of approximately $98 \%$ which indicated excellent digestion and recovery of the MA and PF digestions and the ICP analysis. A comparison of the normalized sump solids composition to that of Frit 418 yields very little difference in the four major oxides. 
Table 1. Elemental Results for the Sump Solids (calcined, elemental wt\% basis).

\begin{tabular}{|c|c|c|c|c|c|}
\hline \multirow[b]{2}{*}{ Element } & \multirow[b]{2}{*}{ Digestion $^{d}$} & \multirow[b]{2}{*}{$\begin{array}{l}\text { Analytical } \\
\text { Method }^{\mathrm{e}}\end{array}$} & \multicolumn{3}{|c|}{ Average } \\
\hline & & & $\begin{array}{c}\text { wt\% } \\
\text { (elemental) }\end{array}$ & STDEV & \%RSD \\
\hline $\mathrm{Ag}$ & MA & ICP-ES & $<0.0021$ & - & - \\
\hline $\mathrm{Al}$ & $\mathrm{PF}$ & ICP-ES & 0.22 & 0.02 & 9.9 \\
\hline As & MA & $\mathrm{AA}$ & $<0.0014$ & - & - \\
\hline $\mathrm{B}$ & $\mathrm{PF}$ & ICP-ES & 2.33 & 0.02 & 0.95 \\
\hline $\mathrm{Ba}$ & MA & ICP-ES & 0.00123 & 0.00005 & 4.1 \\
\hline $\mathrm{Be}$ & MA & ICP-ES & $<0.0007$ & - & - \\
\hline $\mathrm{Ca}$ & MA & ICP-ES & 0.023 & 0.003 & 11.0 \\
\hline $\mathrm{Cd}$ & MA & ICP-ES & $<0.0013$ & - & - \\
\hline $\mathrm{Ce}$ & MA & ICP-ES & $<0.0066$ & - & - \\
\hline Co & MA & ICP-ES & $<0.0008$ & - & - \\
\hline $\mathrm{Cr}$ & MA & ICP-ES & 0.026 & 0.001 & 4.8 \\
\hline $\mathrm{Cu}$ & MA & ICP-ES & $<0.0014$ & - & - \\
\hline $\mathrm{Fe}$ & PF/MA & ICP-ES & 0.13 & 0.02 & 13.5 \\
\hline $\mathrm{Gd}$ & MA & ICP-ES & $<0.0021$ & - & - \\
\hline $\mathrm{Hg}$ & MA & CVAA & $<0.0055$ & - & - \\
\hline $\mathrm{K}$ & MA & ICP-ES & 0.026 & 0.003 & 10.9 \\
\hline $\mathrm{La}$ & MA & ICP-ES & $<0.0011$ & - & - \\
\hline $\mathrm{Li}$ & PF/MA & ICP-ES & 3.56 & 0.09 & 2.4 \\
\hline $\mathrm{Mg}$ & $\mathrm{PF} / \mathrm{MA}$ & ICP-ES & 0.0072 & 0.0008 & 11.8 \\
\hline $\mathrm{Mn}$ & MA & ICP-ES & 0.0027 & 0.0002 & 5.8 \\
\hline Mo & MA & ICP-ES & 0.0073 & 0.0003 & 4.3 \\
\hline $\mathrm{Na}$ & MA & ICP-ES & 5.7 & 0.2 & 3.1 \\
\hline $\mathrm{Ni}$ & MA & ICP-ES & 0.0135 & 0.0002 & 1.5 \\
\hline $\mathrm{P}$ & MA & ICP-ES & $<0.0085$ & - & - \\
\hline $\mathrm{Pb}$ & MA & ICP-ES & $<0.0073$ & - & - \\
\hline $\mathrm{S}$ & MA & ICP-ES & $<0.0747$ & - & - \\
\hline $\mathrm{Sb}$ & MA & ICP-ES & $<0.0069$ & - & - \\
\hline $\mathrm{Se}$ & MA & $\mathrm{AA}$ & $<0.0027$ & - & - \\
\hline $\mathrm{Si}$ & $\mathrm{PF}$ & ICP-ES & 34.9 & 1.5 & 4.4 \\
\hline $\mathrm{Sn}$ & MA & ICP-ES & $<0.0085$ & - & - \\
\hline $\mathrm{Sr}$ & MA & ICP-ES & 0.00032 & 0.00001 & 4.5 \\
\hline $\mathrm{Th}$ & MA & ICP-ES & $<0.0089$ & - & - \\
\hline $\mathrm{Ti}$ & MA & ICP-ES & 0.00581 & 0.00008 & 1.4 \\
\hline $\mathrm{U}$ & MA & ICP-ES & $<0.0443$ & - & - \\
\hline $\mathrm{V}$ & MA & ICP-ES & $<0.0010$ & - & - \\
\hline $\mathrm{Zn}$ & MA & ICP-ES & $<0.0030$ & - & - \\
\hline $\mathrm{Zr}$ & MA & ICP-ES & 0.0049 & 0.0002 & 3.8 \\
\hline
\end{tabular}

${ }^{\mathrm{d}}$ MA: Mixed Acid; PF: Peroxide Fusion

e ICP-EA: Inductively Coupled Plasma-Energy Spectroscopy; CVAA: Cold Vapor Atomic Absorption 
Table 2. Compositional Comparison of the Sump Solids and Nominal Frit 418 (Oxide Basis).

\begin{tabular}{||c|c|c|c||}
\hline \hline & \multicolumn{2}{|c|}{ Sump Solids } & Nominal Frit 418 \\
\hline Oxide & Measured & Normalized & Oxide \\
\hline $\mathrm{Al}_{2} \mathrm{O}_{3}$ & 0.41 & 0.42 & - \\
\hline $\mathrm{B}_{2} \mathrm{O}_{3}$ & 7.51 & 7.65 & 8 \\
\hline $\mathrm{CaO}$ & 0.03 & 0.03 & - \\
\hline $\mathrm{Cr}_{2} \mathrm{O}_{3}$ & 0.04 & 0.04 & - \\
\hline $\mathrm{Fe}_{2} \mathrm{O}_{3}$ & 0.19 & 0.20 & - \\
\hline $\mathrm{Li}_{2} \mathrm{O}$ & 7.66 & 7.81 & 8 \\
\hline $\mathrm{MgO}$ & 0.01 & 0.01 & - \\
\hline $\mathrm{MnO}_{2}$ & 0.00 & 0.00 & - \\
\hline $\mathrm{Na}_{2} \mathrm{O}$ & 7.66 & 7.80 & 8 \\
\hline $\mathrm{NiO} \mathrm{O}$ & 0.02 & 0.02 & - \\
\hline $\mathrm{SiO}$ & 74.59 & 76.00 & 76 \\
\hline $\mathrm{SrO}$ & 0.00 & 0.00 & - \\
\hline $\mathrm{TiO}$ & 0.01 & 0.01 & - \\
\hline $\mathrm{ZnO}$ & 0.00 & 0.00 & - \\
\hline $\mathrm{ZrO}$ & 0.01 & 0.01 & - \\
\hline $\mathrm{Total}$ & 98.15 & 100.00 & 100.00 \\
\hline \hline
\end{tabular}

\subsubsection{Anion Results}

Table 3 provides a summary of the IC anion results for the sump solids. The results are the average of the four or quadruplicate sump solids analysis (i.e., average of SUMPSOL-1, SUMPSOL-2, SUMPSOL-3, and SUMPSOL-4). The results are presented in the unit of $\mu \mathrm{g} / \mathrm{g}$ (or micrograms of cation/anion per gram of solids).

Table 3. IC Anions Analysis for the Sump Solids.

\begin{tabular}{||l|c||}
\hline Inorganic Species & $\begin{array}{c}\text { Average - } \\
\text { AD Analytical } \\
\text { Results } \\
(\boldsymbol{\mu g} / \mathbf{g} \text { solids })\end{array}$ \\
\hline Ammonia $\left(\mathrm{NH}_{3}\right)$ & $<2.4 \mathrm{E}+03$ \\
\hline Carbonate $\left(\mathrm{CO}_{3}{ }^{2-}\right)$ & $<3.1 \mathrm{E}+03$ \\
\hline Chloride $\left(\mathrm{Cl}^{-}\right)$ & $<4.8 \mathrm{E}+02$ \\
\hline Fluoride $\left(\mathrm{F}^{-}\right)$ & $<4.8 \mathrm{E}+02$ \\
\hline Nitrate $\left(\mathrm{NO}_{3}{ }^{-}\right)$ & $<4.8 \mathrm{E}+02$ \\
\hline Nitrite $\left(\mathrm{NO}_{2}{ }^{-}\right)$ & $<4.8 \mathrm{E}+02$ \\
\hline Oxalate $\left(\mathrm{C}_{2} \mathrm{O}_{4}{ }^{-2}\right)$ & $<4.8 \mathrm{E}+02$ \\
\hline Phosphate $\left(\mathrm{PO}_{4}{ }^{-3}\right)$ & $<2.4 \mathrm{E}+03$ \\
\hline Sulfate $\left(\mathrm{SO}_{4}{ }^{-2}\right)$ & $<4.8 \mathrm{E}+02$ \\
\hline
\end{tabular}




\subsubsection{Radionuclide Results}

Table 4 summarizes radionuclide results from the analysis of the sump solids. The reported values are averages from quadruplicate analysis (i.e., of SUMPSOL-1, SUMPSOL-2, SUMPSOL-3, and SUMPSOL-4).

Table 4. Radionuclide Results for the Sump Solids.

\begin{tabular}{||l|c|c||}
\hline Analyte & Method & $\begin{array}{c}\text { Sump Solids } \\
\text { Average } \\
\text { (dpm/g) }\end{array}$ \\
\hline Alpha & Rad Screen & $1.90 \mathrm{E}+02^{\mathrm{f}}$ \\
\hline $\begin{array}{l}\text { Nonvolatile Beta } \\
\text { (Beta/Gamma) }\end{array}$ & Rad Screen & $<1.73 \mathrm{E}+03$ \\
\hline H-3 & Tritium Count & $<1.18 \mathrm{E}+02$ \\
\hline $\mathrm{C}-14^{\mathrm{g}}$ & & NM \\
\hline Ni-63 & Beta Liq Scint & $<6.56 \mathrm{E}+01$ \\
\hline Co-60 & Gamma Spec & $<5.61 \mathrm{E}+00$ \\
\hline Sr-90 & Beta Liq Scint & $1.30 \mathrm{E}+03$ \\
\hline Tc-99 & Beta Liq Scint & $<3.62 \mathrm{E}+00$ \\
\hline Ru-106 & Gamma Spec & $<4.64 \mathrm{E}+01$ \\
\hline Sn-126 & Gamma Spec & $<1.64 \mathrm{E}+01$ \\
\hline Sb-125 & Gamma Spec & $<2.85 \mathrm{E}+01$ \\
\hline I-129 & Gamma liquid & $<2.21 \mathrm{E}+00$ \\
\hline Cs-137 & Gamma Spec & $3.09 \mathrm{E}+02$ \\
\hline Eu-154 & Gamma Spec & $<1.17 \mathrm{E}+01$ \\
\hline $\mathrm{U}-233$ & ICP-MS & $<1.07 \mathrm{E}+04$ \\
\hline $\mathrm{U}-235$ & ICP-MS & $<2.39 \mathrm{E}+00$ \\
\hline Pu-238 & Pu Alpha & $<8.75 \mathrm{E}+00$ \\
\hline Pu-239/240 & Pu Alpha & $5.60 \mathrm{E}+00^{\mathrm{h}}$ \\
\hline Pu-241 & Liquid Scint & $<2.40 \mathrm{E}+02$ \\
\hline \hline
\end{tabular}

\subsubsection{Organic Species}

Table 5 summarizes the results of the sump solids organic analyses. Again the results are averaged values from the quadruplicate sump solids samples (i.e., SUMPSOL-1, SUMPSOL-2, SUMPSOL-3, and SUMPSOL-4). AD reported most of the VOA and SVOA results under an

\footnotetext{
${ }^{\mathrm{f}}$ The alpha count results for SUMPSOL-1 were reported as $1.90 \mathrm{E}+02 \mathrm{dpm} / \mathrm{g}$ while all other values were reported as " $<$ " values. For SUMPSOL-2, SUMPSOL-3, and SUMPSOL-4 the alpha values were $<6.94 \mathrm{E}+01,<1.08 \mathrm{E}+02$, and $<3.54 \mathrm{E}+01 \mathrm{dpm} / \mathrm{g}$ respectively.

${ }^{\mathrm{g}} \mathrm{C}-14$ was not analyzed for in the sump solids samples based on customer request (see WSRC-NB-99-00002, page 44 for more information).

${ }^{\mathrm{h}}$ The reported $\mathrm{Pu}-239 / 240$ value of $5.60 \mathrm{E}+00 \mathrm{dpm} / \mathrm{g}$ is the average SUMPSOL-1, SUMPSOL-2, and SUMPSOL-3 values. The reported value of SUMPSOL- 4 was $<3.49 \mathrm{E}+00 \mathrm{dpm} / \mathrm{g}$ and was not used in the average calculation.
} 
overarching category (i.e., VOA and SVOA were reported as "not detected" and a detection limit was provided). The reported detection limits for VOA and SVOA were 0.05 and $1.0 \mu \mathrm{g} / \mathrm{g}$, respectively. The reported detection limit for TPB anion was $10 \mu \mathrm{g} / \mathrm{g}$. Total organic carbon was determined from weighted dilutions of the sump solids using nominally $0.5 \mathrm{~g}$ of solid added to 50 $\mathrm{mL}$ of deionized water. The reported detection limit for the TOC method was $1.25 \mathrm{ug} \mathrm{C} / \mathrm{mL}$ solution. Converting this reported detection limit using the weighted dilution factor of 50 $\mathrm{mL} / 0.1 \mathrm{~g}$, gives the reported detection limit of $625 \mu \mathrm{g} \mathrm{C} / \mathrm{g}$.

Table 5. Organic Results for the Sump Solids.

\begin{tabular}{|c|c|}
\hline Constituent/Property & $\begin{array}{c}\text { Sump Solids Average } \\
(\mu \mathrm{g} / \mathrm{g} \text { of solids) }\end{array}$ \\
\hline VOA (all analytes) & $<0.05$ \\
\hline Benzene & $<0.05$ \\
\hline Toluene & $<0.05$ \\
\hline Trichloroethylene (TCE) & $<0.05$ \\
\hline Tetrachloroethylene (PCE) & $<0.05$ \\
\hline SVOA (all analytes) & $<1$ \\
\hline Phenol & $<1$ \\
\hline PCBs (all analytes) & $<1$ \\
\hline Tetraphenylborate (TPB) & $<10$ \\
\hline TOC & $<6.25 \mathrm{E}+02$ \\
\hline $\mathrm{pH}$ & NA \\
\hline
\end{tabular}

\section{2 $\underline{\text { Slurry Solids }}$}

In this section the results of the physical (XRD, SEM with EDS, and PSD) and chemical characterization of the slurry solids are presented and discussed.

\subsubsection{Physical Characterization}

\subsubsection{XRD Results}

The result of the XRD analysis of the slurry solids sample is shown in Figure 15. As with the sump solids sample, the primary physical characteristic is an amorphous hump which indicates that the slurry solid sample is amorphous (or glass). However, unlike the sump solids, the XRD for the slurry solids also shows a small peak at $2.0733^{\circ} 2$-theta which was identified as Taenite (an Fe-Ni compound). The presence of $\mathrm{Fe}$ and $\mathrm{Ni}$ in this sample is most likely due to stainless contamination which was observed in the sump solids SEM/EDS analysis (see Section 3.2.1.2 for the SEM/EDS analysis of the slurry solids). Again the XRD results are consistent with a Frit 418 based sample with minor amounts of stainless steel impurities (from the canister decon process). 


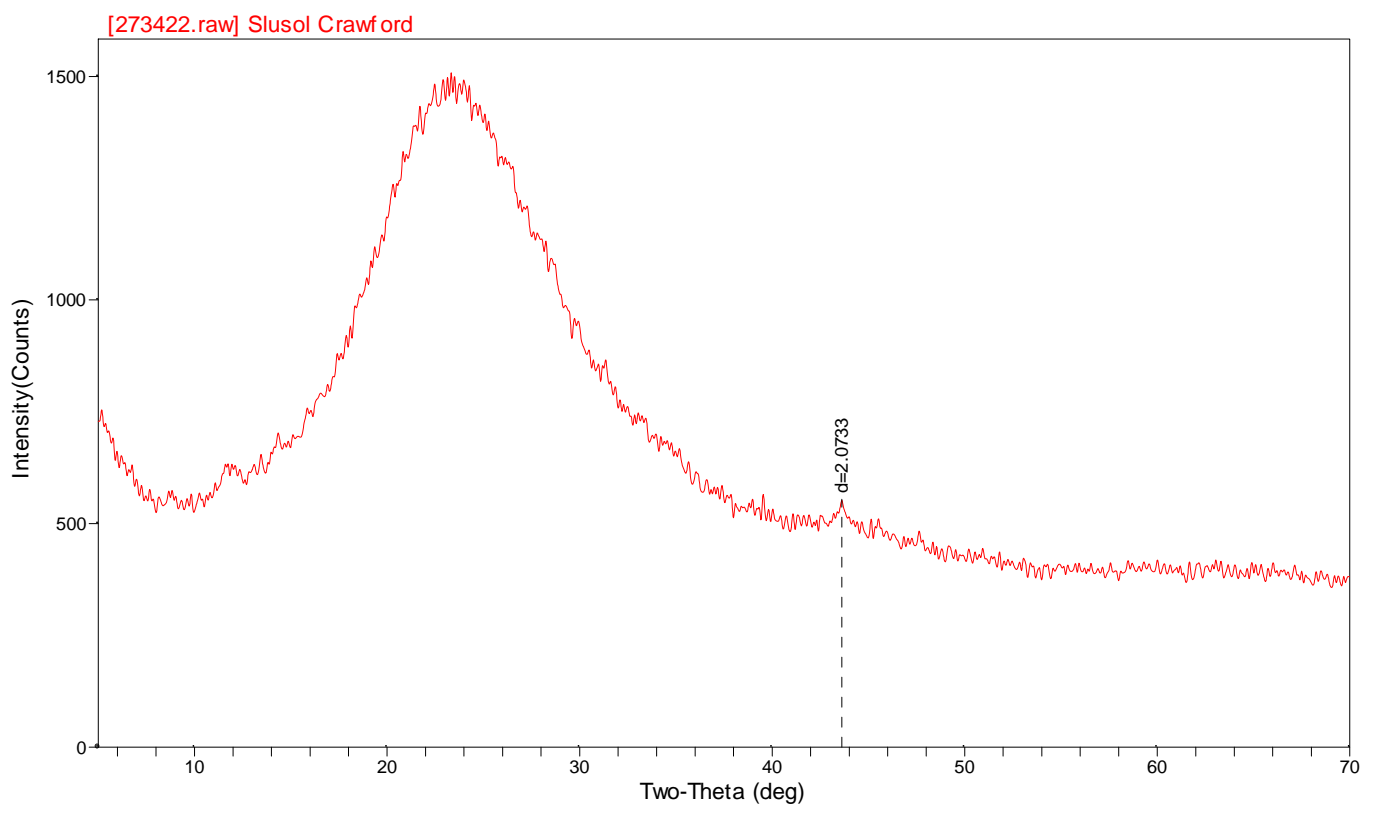

Figure 15. XRD Results of Slurry Solids Samples.

\subsubsection{SEM/EDS Results}

Figure 16 provides a low magnification (17x) micrograph of the slurry solids sample. Figure 17 shows a SEM micrograph (at the same magnification) of Frit 418 as received from a vendor (identical to Figure 9). A comparison of the two figures indicates that the slurry solids have a much broader particle size distribution and the majority of those particles are extremely small. This is likely due to the fact that some fraction of the solids were suspended in the supernate (i.e., the fines particles of Frit 418 did not settle prior to the sample being taken). As will be discussed, there are "impurities" observed in the slurry solids SEM analysis (shown as "bright" spots in Figure 16).

Figures 18 and 19 provide a higher magnification photo of the slurry solid sample and the corresponding SEM/EDS analysis (of Spot \#3 in Figure 18), respectively. The SEM/EDS analysis (Figure 19) indicates that $\mathrm{Na}$ and $\mathrm{Si}$ are present in these five spot analyses. Again, the presence of $\mathrm{B}$ and $\mathrm{Li}$ are not detectable with the EDS system. These results are consistent with presence of Frit 418 (although quantitative information can not be easily surmised from the EDS analysis).

Figure 20 provides another higher magnification micrograph of the slurry solids. In this figure, "impurities" are observed (as denoted by the presence of bright spots on the surface of several frit particles; also labeled as Spot 1 and Spot 2). Figure 21 is the EDS spectra for Spot 1 which indicates that the spots contain $\mathrm{Fe}, \mathrm{Ni}$, and $\mathrm{Cr}$. These elements are consistent with the presence of stainless steel (supporting XRD identification of the Fe-Ni compound Taenite (see Figure 15)). Figure 22 shows the EDS spectra for Spot 2 (of Figure 20). These results indicate the presence of $\mathrm{Pb}$ (major source), $\mathrm{Mg}, \mathrm{Zn}$, and $\mathrm{Ta}$. These elements are not likely associated with stainless but 
(speculation only) perhaps some source of solder that may have been used in the decon frit piping system. ${ }^{\text {i }}$

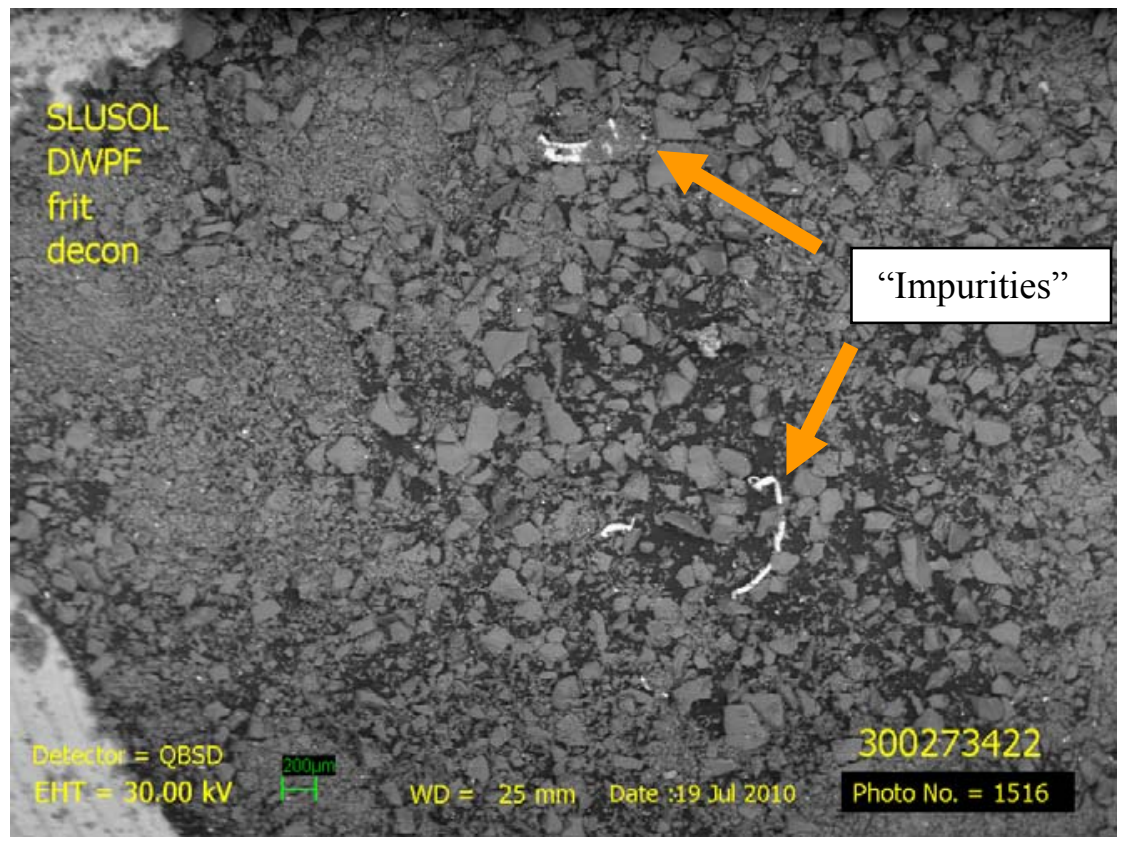

Figure 16. SEM Micrograph of Slurry Solids Sample.

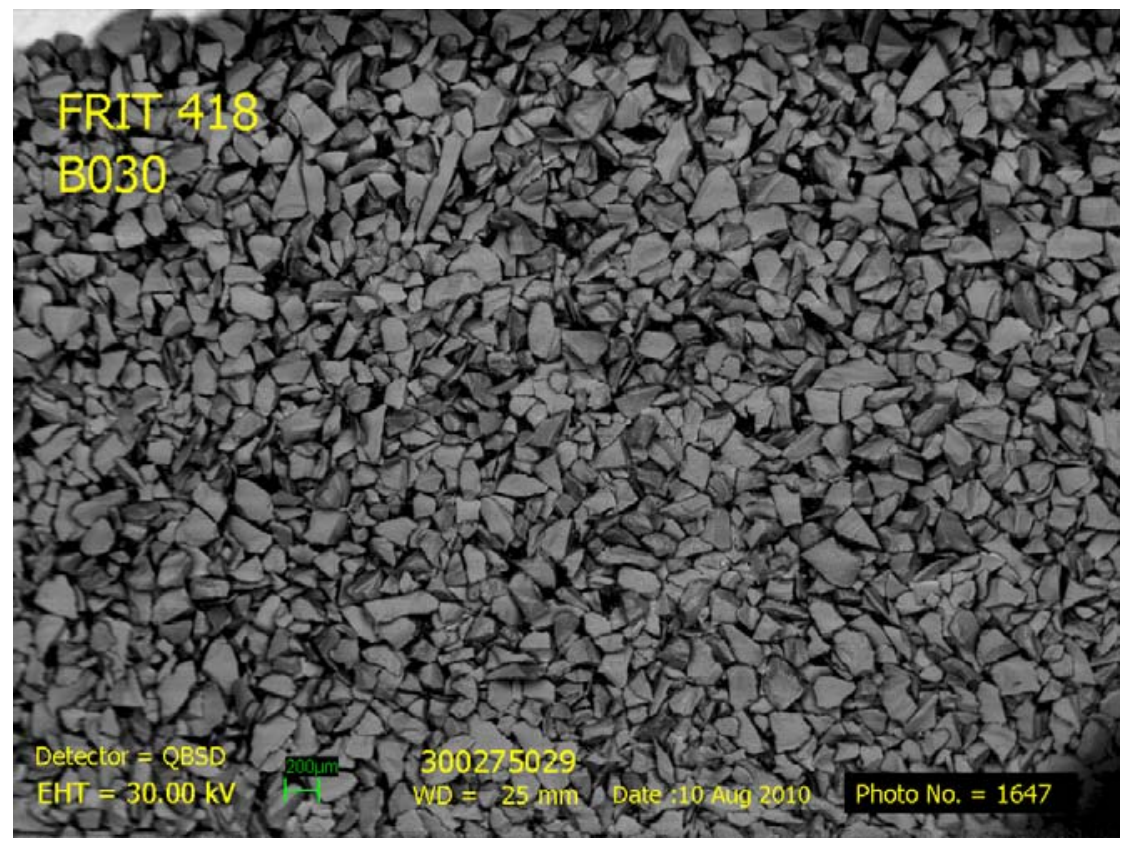

Figure 17. SEM Micrograph of Frit 418 (as received from vendor).

\footnotetext{
${ }^{\mathrm{i}}$ For detailed information on the SEM/EDS analysis of the slurry solids, refer to WSRC-NB-99-00002, pages 66 through 74 .
} 


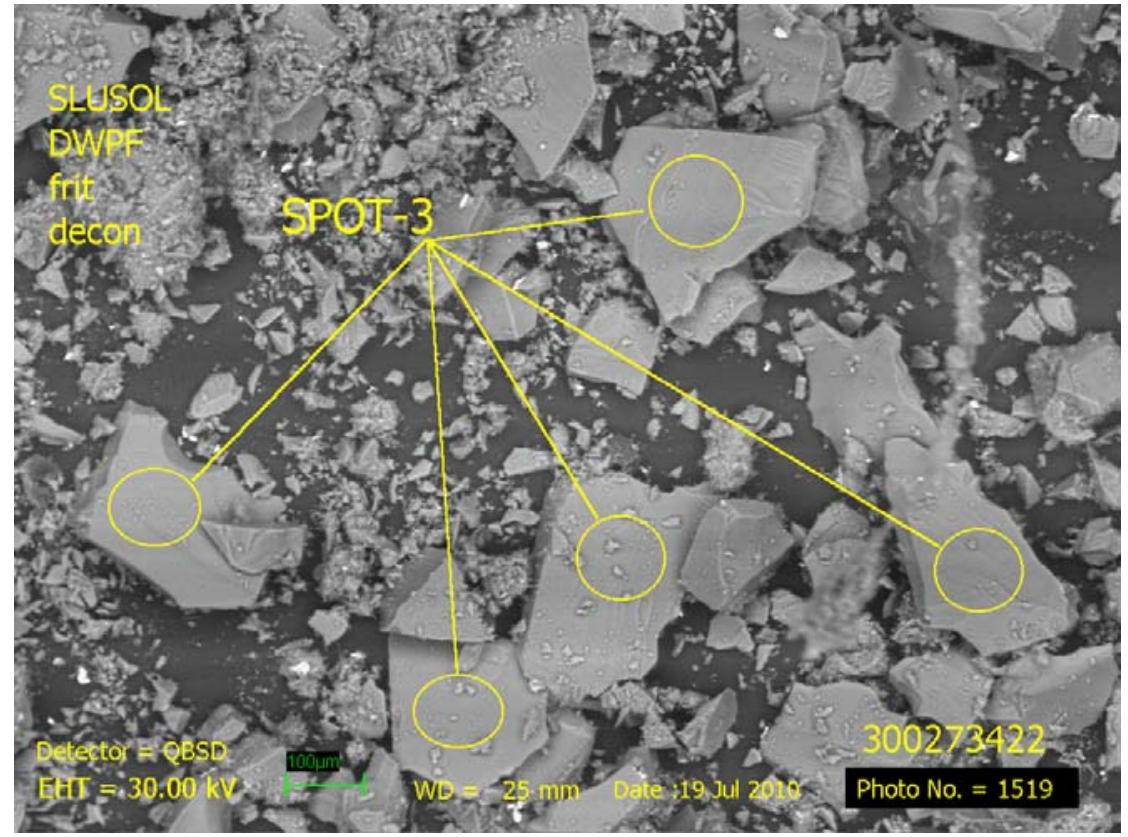

Figure 18. SEM Micrograph of Various Slurry Solids Frit Particles.

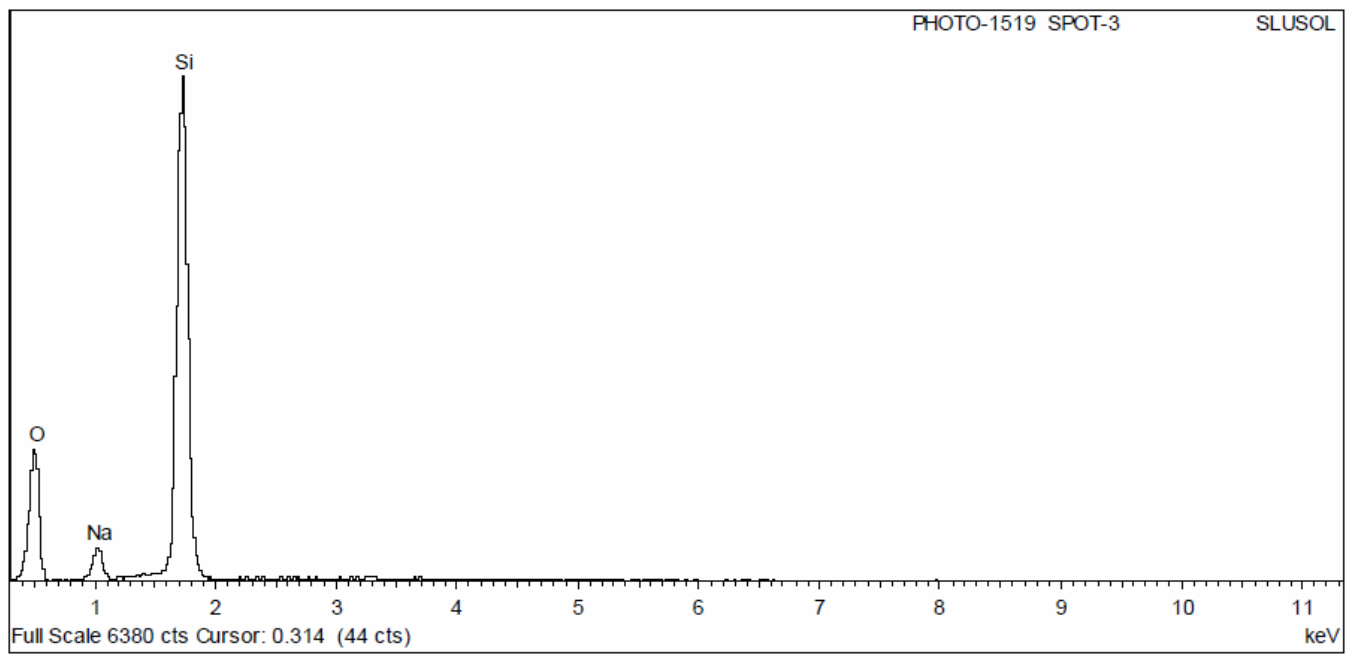

Figure 19. EDS Analysis of Spot 3 (see Figure 18). 


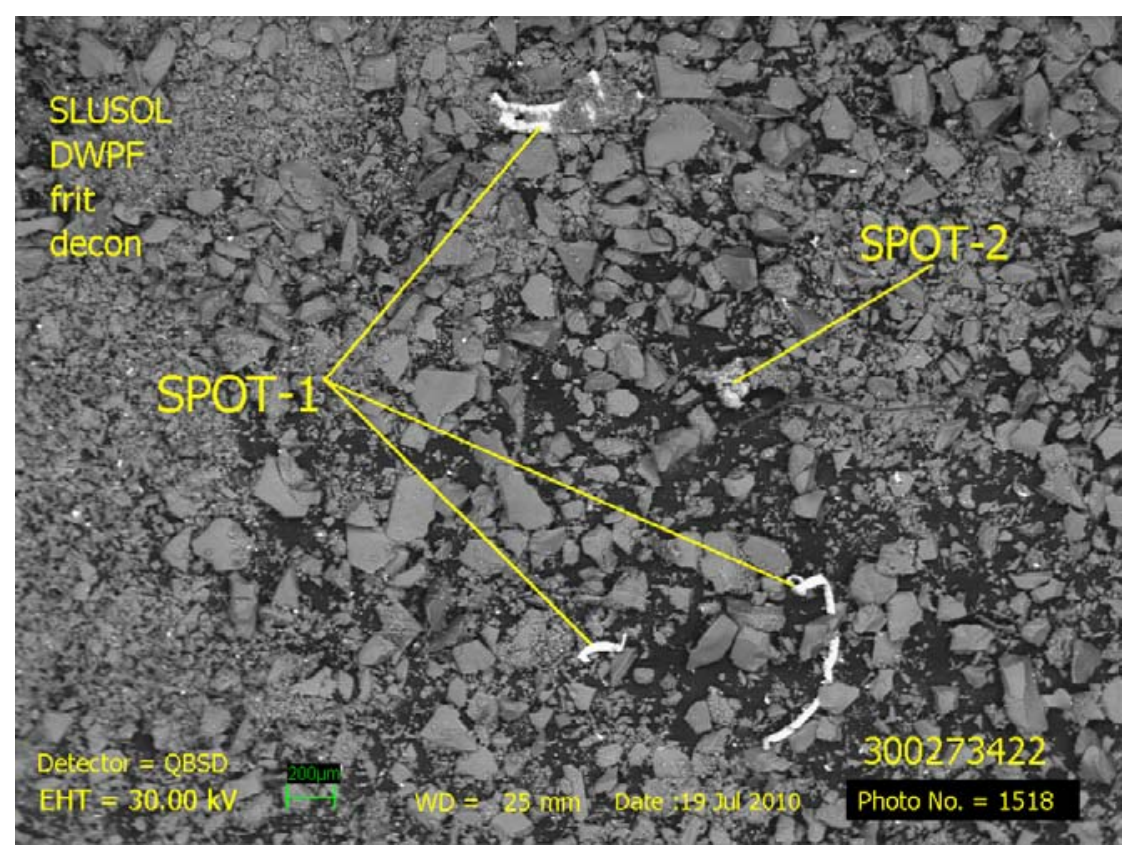

Figure 20. SEM Micrograph (higher magnification) of Sump Solids Showing Impurities.

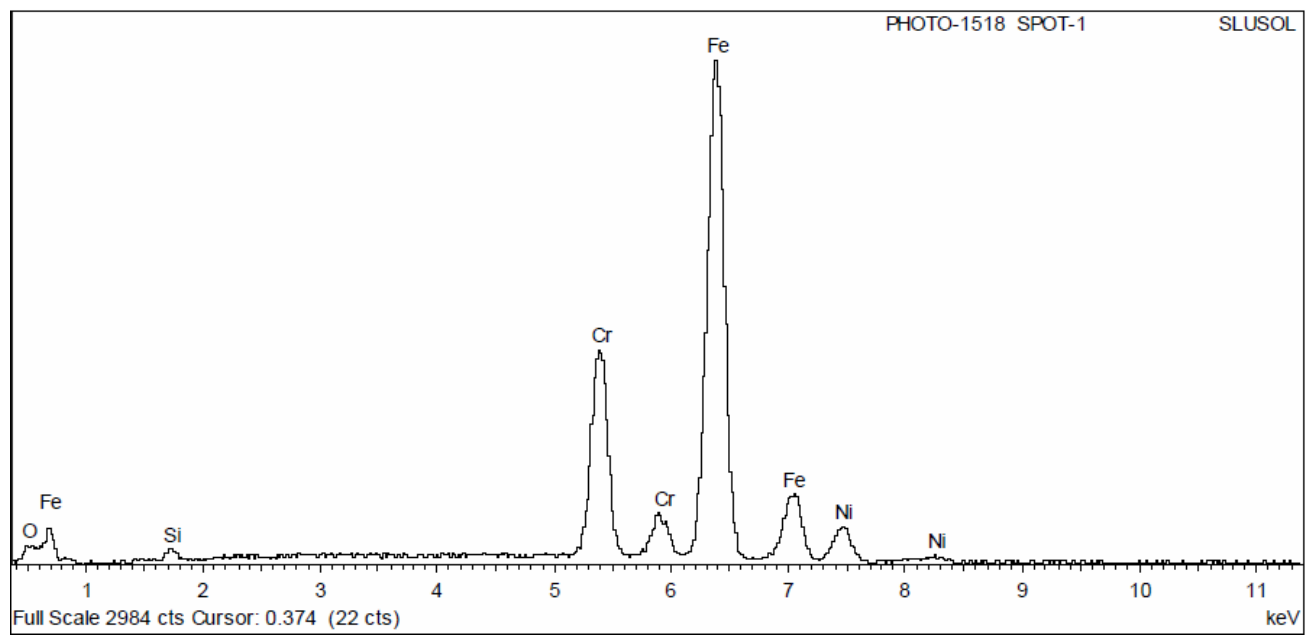

Figure 21. EDS Analysis of Spot 1 of Figure 20 (Slurry Solids). 


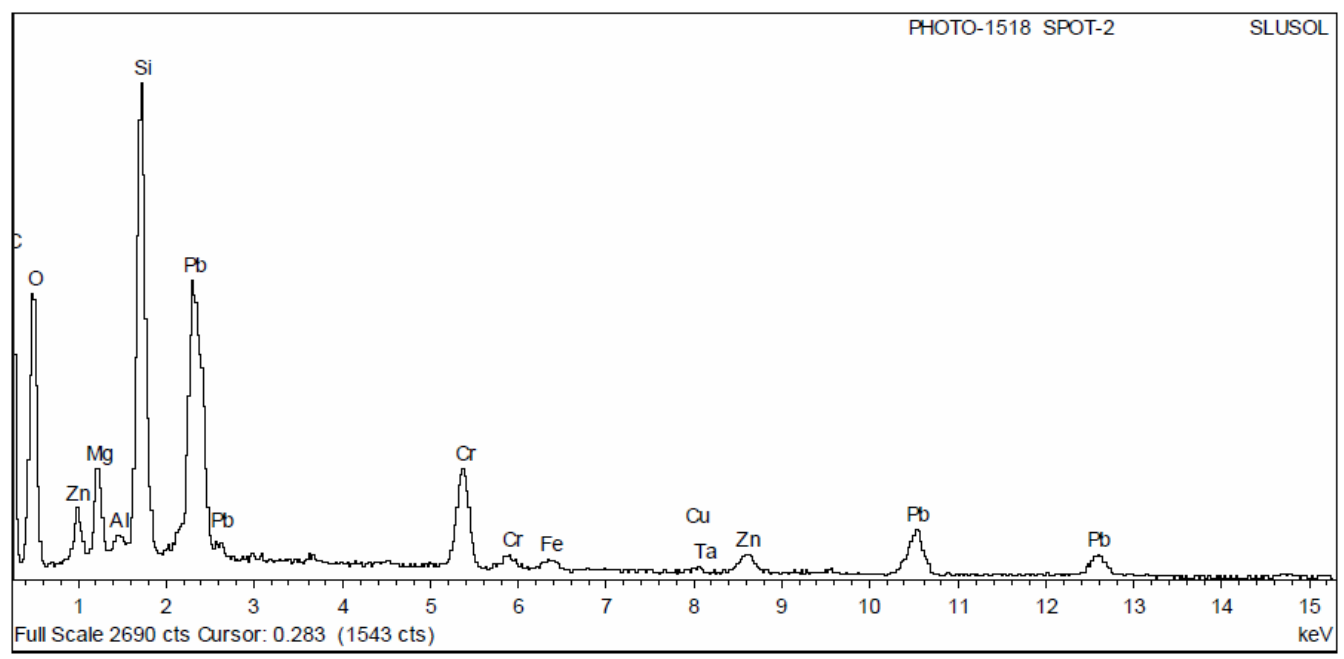

Figure 22. EDS Analysis of Spot \#2 of Figure 20 (Slurry Solids).

\subsubsection{Particle Size Analysis}

Figure 23 provides the PSD results of the slurry solids. The particle size distribution was measured in terms of the volume of particles. An equivalent spherical diameter is then calculated and the distribution is shown in Figure 23. Based on these results, approximately $99.5 \%$ of the particles are less then 350 microns. SEM analysis of the slurry solids (as compared to the as received Frit 418 or sump solids) suggested that there was a significant fraction of the sample composed of smaller particles. This shift in the size distribution is also shown through the PSD analysis (i.e., the enhanced "tail" on the PSD plot (Figure 23)). In fact, approximately 15 $20 \%$ of the slurry solids particles are then less than 20 microns as compared to less than $0.5 \%$ for the sump solids. Again, the shift to smaller particle sizes for the slurry solids can be attributed to fines remaining in suspension after the $\sim 3$ days of settling. It is possible that a higher percentage of the total slurry solid particle sizes are less than 20 microns due to initial decanting of the settled solutions to prepare sample aliquots for the supernate analyses. In order to determine the actual distribution of the slurry solids in a representative sample, one would need to filter the entire sample, e.g., using a nominal 0.45 micron filter, without pre-decanting of any supernatant before filtration. 


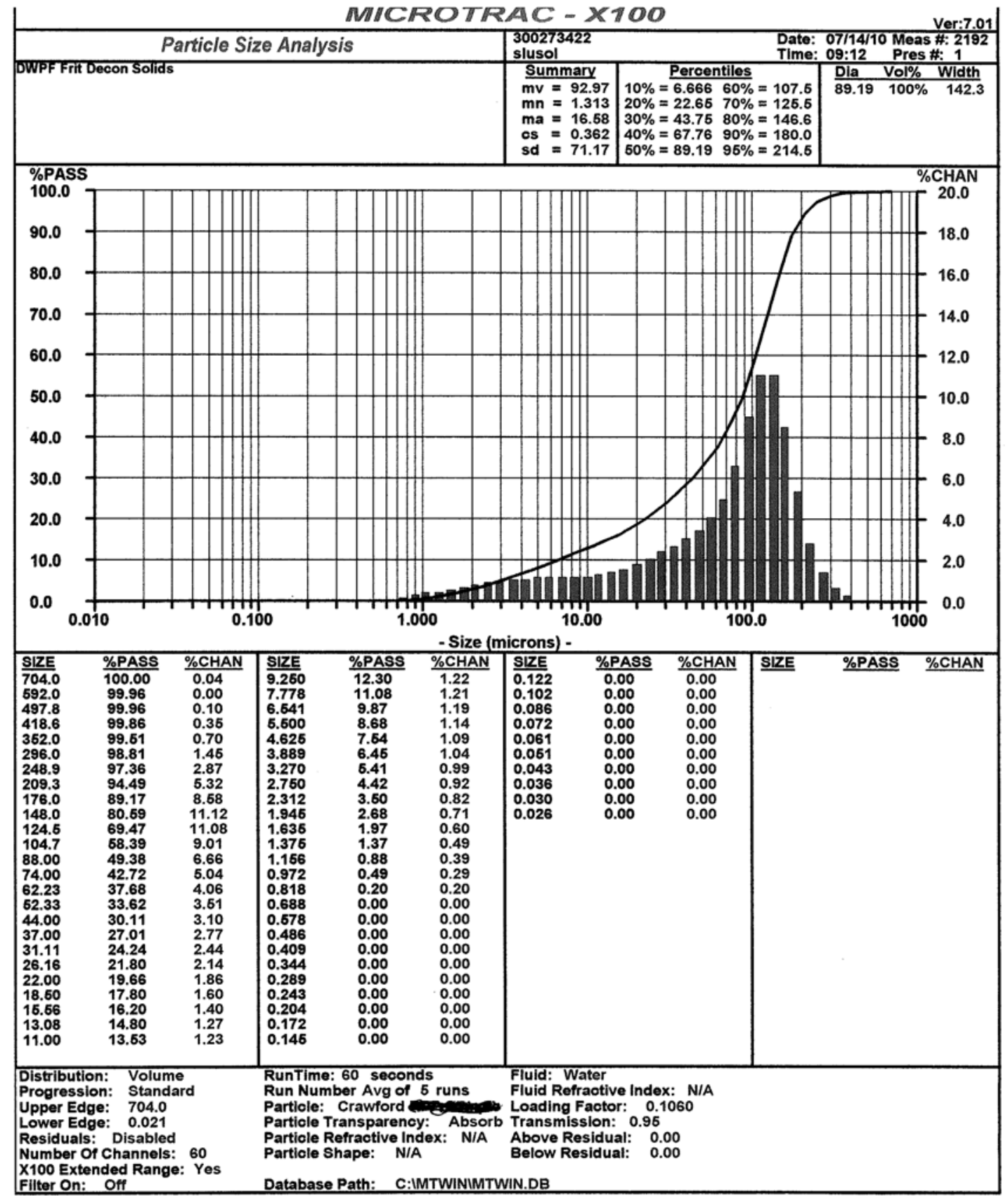

Figure 23. Particle Size Distribution Results of the Sump Solids. 


\subsubsection{Chemical Characterization}

To support compositional analysis of the slurry solids, four representative samples were provided to AD. As with the sump solids, the slurry samples were dissolved using both PF and MA techniques. The solutions were then analyzed by ICP-AES or AA. The averaged results of the quadruplicate analysis are shown in Table 6. Also shown in Table 6 are the specific digestion method (PF and/or MA) and analytical technique that were used to compute the average for each element. For example, the average Al concentration was computed from the four ICP-AES values resulting from the $\mathrm{PF}$ digestion. For Fe, the averaged concentration was reported from the eight ICP-AES results (4 from PF and 4 from MA). The standard deviation (STDEV) and percent relative standard deviations are also provided when appropriate (i.e., when values were above detection limits). Note that the results shown in Table 6 are on a calcined elemental basis not on a volume basis (i.e., the 2.388 grams of solids per 4 liters of supernate have not been accounted for in the values reported in Table 6). ${ }^{\mathrm{j}}$

Given the use of Frit 418 during sampling for this task, the elemental values of B, Li, Na, and $\mathrm{Si}$ are highlighted in Table 6 . As expected, these four components are the major contributors in the sump solids analysis. In addition to major components ( $\mathrm{B}, \mathrm{Li}, \mathrm{Na}$, and $\mathrm{Si}$ ), the ICP-AES results also provide measurable concentrations for $\mathrm{Al}, \mathrm{Ca}, \mathrm{Cr}, \mathrm{Fe}, \mathrm{Mg}, \mathrm{Mn}, \mathrm{Ni}, \mathrm{Sr}, \mathrm{Ti}, \mathrm{Zn}$, and $\mathrm{Zr}$. The presence of stainless steel and impurities in the "as received" frit could account for most of the minor elemental contribution to the slurry solid compositional results.

The elemental information in Table 6 was converted to an oxide basis for a direct comparison with the nominal Frit 418 composition. Table 7 shows the measured and normalized (to $100 \%$ ) composition of the slurry solids analysis as well as the nominal Frit 418 composition. The four major oxides of Frit 418 are shaded to aid in the comparison. The measured slurry solids data provide a sum of oxides of approximately $98.5 \%$ which indicates excellent digestion and recovery of the MA and PF preps and the ICP-AES and AA analyses. A comparison of the normalized sump solids composition to that of Frit 418 yields very little difference in the four major oxides.

\footnotetext{
${ }^{\mathrm{j}}$ Table 8 provides the results of the inorganic species on a mass per volume of solution basis.
} 
Table 6. Elemental Results for the Slurry Solids (calcined, elemental wt\%).

\begin{tabular}{|c|c|c|c|c|c|}
\hline \multirow[b]{2}{*}{ Element } & \multirow[b]{2}{*}{ Digestion $^{k}$} & \multirow[b]{2}{*}{$\begin{array}{c}\text { Analytical } \\
\text { Method }^{1}\end{array}$} & \multicolumn{3}{|c|}{ Average } \\
\hline & & & $\begin{array}{c}\text { wt\% } \\
\text { (elemental) }\end{array}$ & STDEV & \%RSD \\
\hline $\mathrm{Ag}$ & MA & ICP-ES & $<0.0184$ & - & - \\
\hline $\mathrm{Al}$ & $\mathrm{PF}$ & ICP-ES & 0.21 & 0.03 & 15.4 \\
\hline As & MA & AA & $<0.00272$ & - & - \\
\hline $\mathrm{B}$ & $\mathrm{PF}$ & ICP-ES & 2.24 & 0.02 & 0.7 \\
\hline $\mathrm{Ba}$ & $\mathrm{MA}$ & ICP-ES & $<0.0058$ & - & - \\
\hline $\mathrm{Be}$ & MA & ICP-ES & $<0.0007$ & - & - \\
\hline $\mathrm{Ca}$ & MA & ICP-ES & 0.06 & 0.01 & 18.1 \\
\hline $\mathrm{Cd}$ & MA & ICP-ES & $<0.0035$ & - & - \\
\hline $\mathrm{Ce}$ & MA & ICP-ES & $<0.0631$ & - & - \\
\hline $\mathrm{Co}$ & MA & ICP-ES & $<0.0084$ & - & - \\
\hline $\mathrm{Cr}$ & PF/MA & ICP-ES & 0.12 & 0.03 & 25.3 \\
\hline $\mathrm{Cu}$ & MA & ICP-ES & $<0.0140$ & - & - \\
\hline $\mathrm{Fe}$ & PF/MA & ICP-ES & 0.6 & 0.1 & 20.2 \\
\hline $\mathrm{Gd}$ & MA & ICP-ES & $<0.0134$ & - & - \\
\hline $\mathrm{Hg}$ & MA & CVAA & $<0.0109$ & - & - \\
\hline $\mathrm{K}$ & MA & ICP-ES & $<0.1980$ & - & - \\
\hline $\mathrm{La}$ & MA & ICP-ES & $<0.0107$ & - & - \\
\hline $\mathrm{Li}$ & PF/MA & ICP-ES & 3.5 & 0.2 & 7.03 \\
\hline $\mathrm{Mg}$ & PF/MA & ICP-ES & 0.019 & 0.007 & 38.1 \\
\hline $\mathrm{Mn}$ & PF/MA & ICP-ES & 0.016 & 0.005 & 28.5 \\
\hline Mo & MA & ICP-ES & $<0.0283$ & - & - \\
\hline $\mathrm{Na}$ & MA & ICP-ES & 5.4 & 0.6 & 10.5 \\
\hline $\mathrm{Ni}$ & PF/MA & ICP-ES & 0.09 & 0.02 & 26.2 \\
\hline $\mathrm{P}$ & MA & ICP-ES & $<0.0839$ & - & - \\
\hline $\mathrm{Pb}$ & MA & ICP-ES & $<0.0722$ & - & - \\
\hline $\mathrm{S}$ & MA & ICP-ES & $<0.7410$ & - & - \\
\hline $\mathrm{Sb}$ & MA & ICP-ES & $<0.0680$ & - & - \\
\hline $\mathrm{Se}$ & $\mathrm{MA}$ & $\mathrm{AA}$ & $<0.0054$ & - & - \\
\hline $\mathrm{Si}$ & $\mathrm{PF}$ & ICP-ES & 34.9 & 0.5 & 1.31 \\
\hline $\mathrm{Sn}$ & MA & ICP-ES & $<0.0424$ & - & - \\
\hline $\mathrm{Sr}$ & $\mathrm{PF}$ & ICP-ES & 0.0033 & 0.0002 & 5.55 \\
\hline $\mathrm{Th}$ & MA & ICP-ES & $<0.0515$ & - & - \\
\hline $\mathrm{Ti}$ & PF/MA & ICP-ES & 0.009 & 0.001 & 13.3 \\
\hline $\mathrm{U}$ & MA & ICP-ES & $<0.4390$ & - & - \\
\hline $\mathrm{V}$ & MA & ICP-ES & $<0.0051$ & - & - \\
\hline $\mathrm{Zn}$ & PF/MA & ICP-ES & 0.016 & 0.005 & 28.8 \\
\hline $\mathrm{Zr}$ & MA & ICP-ES & 0.0052 & 0.0001 & 1.49 \\
\hline
\end{tabular}

${ }^{\mathrm{k}}$ MA: Mixed Acid; PF: Peroxide Fusion

${ }^{1}$ ICP-EA: Inductively Coupled Plasma-Energy Spectroscopy; CVAA: Cold Vapor Atomic Absorption 
Table 7. Comparison of the Slurry Solids and Nominal Frit 418 Composition (Oxide Basis).

\begin{tabular}{||c|c|c|c||}
\hline & \multicolumn{2}{|c|}{ Slurry Solids } & Nominal Frit 418 \\
\hline Oxide & Measured & Normalized & Oxide \\
\hline $\mathrm{Al}_{2} \mathrm{O}_{3}$ & 0.40 & 0.41 & - \\
\hline $\mathrm{B}_{2} \mathrm{O}_{3}$ & 7.21 & 7.32 & 8 \\
\hline $\mathrm{CaO}$ & 0.08 & 0.08 & - \\
\hline $\mathrm{Cr}_{2} \mathrm{O}_{3}$ & 0.17 & 0.18 & - \\
\hline $\mathrm{Fe}_{2} \mathrm{O}_{3}$ & 0.83 & 0.84 & - \\
\hline $\mathrm{Li}_{2} \mathrm{O}$ & 7.60 & 7.71 & 8 \\
\hline $\mathrm{MgO}$ & 0.03 & 0.03 & - \\
\hline $\mathrm{MnO}_{2}$ & 0.02 & 0.02 & - \\
\hline $\mathrm{Na}_{2} \mathrm{O}$ & 7.31 & 7.42 & 8 \\
\hline $\mathrm{NiO}_{\mathrm{SiO}}$ & 0.11 & 0.11 & - \\
\hline $\mathrm{SiO}$ & 74.72 & 75.83 & 76 \\
\hline $\mathrm{SrO}$ & 0.00 & 0.00 & - \\
\hline $\mathrm{TiO}$ & 0.01 & 0.01 & - \\
\hline $\mathrm{ZnO}$ & 0.02 & 0.02 & - \\
\hline $\mathrm{ZrO}$ & 0.01 & 0.01 & - \\
\hline & & & 100.00 \\
\hline $\mathrm{Total}$ & 98.52 & 100.00 & \\
\hline
\end{tabular}

Table 8 provides the inorganic results on a volume basis $(\mathrm{mg} / \mathrm{mL})$ based on the fact that 2.388 grams of slurry solids were filtered or recovered from $\sim 4 \mathrm{~L}$ of supernate. These values were calculated to be compared to previously presented data in the supernate report Crawford and Peeler (2010). So these data indicate the contribution of the inorganic analytes derived from the insoluble solids that were present in the original 4 Liters of sample received. 
Table 8. Elemental Results for the Slurry Solids (volume basis; mg/mL). (volume basis based on 2.388 grams of slurry solids per 4 liters of supernate).

\begin{tabular}{|c|c|c|}
\hline \multirow[b]{2}{*}{ Element } & \multirow[b]{2}{*}{$\begin{array}{c}\text { Digestion/Analytical } \\
\text { Method }\end{array}$} & \multirow{2}{*}{$\begin{array}{c}\text { Average } \\
\text { Volume Basis } \\
(\mathrm{mg} / \mathrm{mL})\end{array}$} \\
\hline & & \\
\hline $\mathrm{Ag}$ & MA & $<1.10 \mathrm{E}-04$ \\
\hline $\mathrm{Al}$ & $\mathrm{PF}$ & $1.28 \mathrm{E}-03$ \\
\hline As & AA & $<1.62 \mathrm{E}-05$ \\
\hline $\mathrm{B}$ & $\mathrm{PF}$ & $1.34 \mathrm{E}-02$ \\
\hline $\mathrm{Ba}$ & MA & $<3.48 \mathrm{E}-05$ \\
\hline $\mathrm{Be}$ & MA & $<4.13 \mathrm{E}-06$ \\
\hline $\mathrm{Ca}$ & MA & $3.32 \mathrm{E}-04$ \\
\hline $\mathrm{Cd}$ & MA & $<2.07 \mathrm{E}-05$ \\
\hline $\mathrm{Ce}$ & MA & $<3.77 \mathrm{E}-04$ \\
\hline $\mathrm{Co}$ & MA & $<5.01 \mathrm{E}-05$ \\
\hline $\mathrm{Cr}$ & PF/MA & $7.06 \mathrm{E}-04$ \\
\hline $\mathrm{Cu}$ & MA & $<8.36 \mathrm{E}-05$ \\
\hline $\mathrm{Fe}$ & PF/MA & $3.45 \mathrm{E}-03$ \\
\hline Gd & MA & $<8.00 \mathrm{E}-05$ \\
\hline $\mathrm{Hg}$ & CVAA & $<6.51 \mathrm{E}-05$ \\
\hline $\mathrm{K}$ & MA & $<1.18 \mathrm{E}-03$ \\
\hline $\mathrm{La}$ & MA & $<6.39 \mathrm{E}-05$ \\
\hline $\mathrm{Li}$ & PF/MA & $2.11 \mathrm{E}-02$ \\
\hline $\mathrm{Mg}$ & $\mathrm{PF} / \mathrm{MA}$ & $1.14 \mathrm{E}-04$ \\
\hline $\mathrm{Mn}$ & PF/MA & $9.66 \mathrm{E}-05$ \\
\hline Mo & MA & $<1.69 \mathrm{E}-04$ \\
\hline $\mathrm{Na}$ & MA & $3.24 \mathrm{E}-02$ \\
\hline $\mathrm{Ni}$ & $\mathrm{PF} / \mathrm{MA}$ & $5.27 \mathrm{E}-04$ \\
\hline $\mathrm{P}$ & MA & $<5.01 \mathrm{E}-04$ \\
\hline $\mathrm{Pb}$ & MA & $<4.31 \mathrm{E}-04$ \\
\hline $\mathrm{S}$ & MA & $<4.42 \mathrm{E}-03$ \\
\hline $\mathrm{Sb}$ & MA & $<4.06 \mathrm{E}-04$ \\
\hline $\mathrm{Se}$ & $\mathrm{AA}$ & $<3.24 \mathrm{E}-05$ \\
\hline $\mathrm{Si}$ & $\mathrm{PF}$ & $2.09 \mathrm{E}-01$ \\
\hline $\mathrm{Sn}$ & MA & $<2.53 \mathrm{E}-04$ \\
\hline $\mathrm{Sr}$ & $\mathrm{PF}$ & $1.96 \mathrm{E}-05$ \\
\hline $\mathrm{Th}$ & MA & $<3.07 \mathrm{E}-04$ \\
\hline $\mathrm{Ti}$ & PF/MA & $5.22 \mathrm{E}-05$ \\
\hline $\mathrm{U}$ & MA & $<2.62 \mathrm{E}-03$ \\
\hline $\mathrm{V}$ & MA & $<3.07 \mathrm{E}-05$ \\
\hline $\mathrm{Zn}$ & PF/MA & $9.37 \mathrm{E}-05$ \\
\hline $\mathrm{Zr}$ & MA & $3.11 \mathrm{E}-05$ \\
\hline
\end{tabular}




\subsubsection{Anion Results}

Table 9 provides a summary of the IC anions for the slurry solids. The results are the average of the four or quadruplicate sump solids analysis (i.e., average of SLUSOL-1, SLUSOL-2,

SLUSOL-3, and SLUSOL-4). The results are presented in micrograms of cation/anion per gram of solids (units of $\mu \mathrm{g} / \mathrm{g}$ ) as well as the milligrams of cation/anion per $\mathrm{mL}$ liter of supernate (units of $\mathrm{mg} / \mathrm{mL}$; accounting for the 2.388 grams of slurry solids filtered from the four liters of supernate).

Table 9. IC Anions for the Slurry Solids (Mass and Volume Basis).

\begin{tabular}{||l|c|c||}
\hline Inorganic Species & $\begin{array}{c}\text { Slurry Solids } \\
\text { Average - } \\
\text { AD Analytical } \\
\text { Results } \\
(\boldsymbol{\mu g} / \mathbf{g} \text { solids })\end{array}$ & $\begin{array}{c}\text { Slurry Solids } \\
\text { Volume Basis } \\
(\mathbf{m g} / \mathbf{m L})\end{array}$ \\
\hline Ammonia $\left(\mathrm{NH}_{3}\right)$ & $<2.5 \mathrm{E}+03$ & $<1.5 \mathrm{E}-03$ \\
\hline Carbonate $\left(\mathrm{CO}_{3}{ }^{2-}\right)$ & $<3.1 \mathrm{E}+03$ & $<1.8 \mathrm{E}-03$ \\
\hline Chloride $\left(\mathrm{Cl}^{-}\right)$ & $<5.0 \mathrm{E}+02$ & $<3.0 \mathrm{E}-04$ \\
\hline Fluoride $\left(\mathrm{F}^{-}\right)$ & $<5.0 \mathrm{E}+02$ & $<3.0 \mathrm{E}-04$ \\
\hline Nitrate $\left(\mathrm{NO}_{3}{ }^{-}\right)$ & $<5.0 \mathrm{E}+02$ & $<3.0 \mathrm{E}-04$ \\
\hline Nitrite $\left(\mathrm{NO}_{2}{ }^{-}\right)$ & $<5.0 \mathrm{E}+02$ & $<3.0 \mathrm{E}-04$ \\
\hline Oxalate $\left(\mathrm{C}_{2} \mathrm{O}_{4}{ }^{-2}\right)$ & $<5.0 \mathrm{E}+02$ & $<3.0 \mathrm{E}-04$ \\
\hline Phosphate $\left(\mathrm{PO}_{4}{ }^{-3}\right)$ & $<2.5 \mathrm{E}+03$ & $<1.5 \mathrm{E}-03$ \\
\hline Sulfate $\left(\mathrm{SO}_{4}^{-2}\right)$ & $<5.0 \mathrm{E}+02$ & $<3.0 \mathrm{E}-04$ \\
\hline \hline
\end{tabular}

\subsubsection{Radionuclide Results}

Table 10 summarizes radionuclide results from the slurry solids. The reported values are averages from quadruplicate analysis (i.e., of SLUSOL-1, SLUSOL-2, SLUSOL-3, and SLUSOL-4). The results are initially reported in $\mathrm{dpm} / \mathrm{g}$ (raw data from AD based on the mass basis radionuclide analysis) and then converted to $\mathrm{dpm} / \mathrm{mL}$ (accounting for the 2.388 grams of slurry solids filtered per four liters of supernate). 
Table 10. Radionuclide Results for the Slurry Solids.

(mass basis in $\mathrm{dpm} / \mathrm{g}$; volume basis $\mathrm{dpm} / \mathrm{mL}$ ).

\begin{tabular}{|c|c|c|}
\hline Analyte & $\begin{array}{l}\text { Mass Basis AD } \\
\text { Analytical } \\
\text { Results (dpm/g) }\end{array}$ & $\begin{array}{c}\text { Volume } \\
\text { Basis } \\
(\mathrm{dpm} / \mathbf{m L})\end{array}$ \\
\hline Alpha $^{\mathrm{m}}$ & $2.94 \mathrm{E}+03$ & $1.75 \mathrm{E}+00$ \\
\hline $\begin{array}{l}\text { Nonvolatile Beta } \\
\text { (Beta/Gamma) }\end{array}$ & $4.38 \mathrm{E}+04$ & $2.61 \mathrm{E}+01$ \\
\hline $\mathrm{H}-3$ & $<3.09 \mathrm{E}+04$ & $<1.84 \mathrm{E}+01$ \\
\hline $\mathrm{C}-14^{\mathrm{n}}$ & NM & NM \\
\hline $\mathrm{Ni}-63^{\circ}$ & $<4.11 \mathrm{E}+04$ & $<2.45 \mathrm{E}+01$ \\
\hline Co-60 & $4.26 \mathrm{E}+04$ & $2.54 \mathrm{E}-03$ \\
\hline Sr-90 & $2.34 \mathrm{E}+04$ & $1.40 \mathrm{E}+01$ \\
\hline Tc-99 & $<1.16 \mathrm{E}+03$ & $<6.93 \mathrm{E}-01$ \\
\hline Ru-106 & $<3.88 \mathrm{E}+01$ & $<2.32 \mathrm{E}-02$ \\
\hline Sn-126 & $<1.57 \mathrm{E}+01$ & $<9.37 \mathrm{E}-03$ \\
\hline Sb-125 & $<3.14 \mathrm{E}+01$ & $<1.87 \mathrm{E}-02$ \\
\hline I-129 & $<6.47 \mathrm{E}+00$ & $<3.86 \mathrm{E}-03$ \\
\hline Cs-137 & $9.90 \mathrm{E}+03$ & $5.91 \mathrm{E}+00$ \\
\hline Eu-154 & $2.40 \mathrm{E}+01$ & $1.43 \mathrm{E}-02$ \\
\hline U-233 & $<1.58 \mathrm{E}+05$ & $<9.43 \mathrm{E}+01$ \\
\hline U-235 & $<2.36 \mathrm{E}+01$ & $<1.41 \mathrm{E}-02$ \\
\hline $\mathrm{Pu}-241$ & $<1.65 \mathrm{E}+04$ & $<9.85 \mathrm{E}+00$ \\
\hline $\mathrm{Pu}-238$ & $<7.02 \mathrm{E}+02$ & $<4.19 \mathrm{E}-01$ \\
\hline $\mathrm{Pu}-239 / 240$ & $<9.33 \mathrm{E}+02$ & $<5.57 \mathrm{E}-01$ \\
\hline $\mathrm{RCG}^{\mathrm{p}}$ & - & $1.41 \mathrm{E}-04$ \\
\hline
\end{tabular}

\subsubsection{Organic Species}

Table 12 summarizes the results of the slurry solids organic analyses. Organic analyses were performed on a single slurry solid sample of $\sim 1$ gram of material remaining after previous slurry solids analyses, i.e., limited $\sim 2.8 \mathrm{~g}$ of slurry solids were consumed for dissolution and analyses for metals and radionuclides. AD reported most of the VOA and SVOA results under an overarching category (i.e., VOA and SVOA were reported as "not detected" and a detection limit was provided). The reported detection limits for VOA and SVOA were 0.5 and $5.0 \mu \mathrm{g} / \mathrm{g}$,

\footnotetext{
${ }^{\mathrm{m}}$ Reported value for alpha count was an average of SLUSOL-1 and SLUSOL-3 given those values were greater than detection limits.

${ }^{\mathrm{n}} \mathrm{C}-14$ was not analyzed for in the sump solids samples based on customer request (see WSRC-NB-99-00002, page 44 for more information).

${ }^{\circ}$ AD did not report a Ni-63 value for SLUSOL-1. Therefore, the reported value in Table 10 is the highest detection limit for SLUSOL-2, SLUSOL-3, and SLUSOL-4.

${ }^{\mathrm{p}} \mathrm{RCG}=(0.000102[\mathrm{Co}-60]+0.00000875[\mathrm{Ru}-106]+0.0000178[\mathrm{Sb}-125]+0.0000324[\mathrm{Cs}-137]+0.0000508[\mathrm{Eu}-$ $154]+0.0000819[\mathrm{Sn}-126])$ (concentration in $\mathrm{dpm} / \mathrm{mL}$ ). Some of the concentrations used in this calculations were "<" values.
} 
respectively. Note that these detection limits are 5 to $10 \mathrm{X}$ higher than those reported for the sump solids due to the limited mass quantity of the slurry solids analyzed. The organic results are initially reported in $\mu \mathrm{g} / \mathrm{g}$ (raw data from AD based on the mass basis organic analysis) and then converted to $\mathrm{mg} / \mathrm{mL}$ (accounting for the 2.388 grams of slurry solids filtered per four liters of supernate).

Table 11. Organic Results for the Slurry Solids.

\begin{tabular}{|c|c|c|}
\hline Constituent/Property & $\begin{array}{l}\text { Slurry Solids } \\
\text { ( } \mu \mathrm{g} / \mathrm{g} \text { solids) }\end{array}$ & $\begin{array}{c}\text { Slurry Solids } \\
\text { Volume Basis } \\
(\mathrm{mg} / \mathrm{mL})\end{array}$ \\
\hline VOA (all analytes) & $<0.5$ & $<2.99 \mathrm{E}-07$ \\
\hline Benzene & $<0.5$ & $<2.99 \mathrm{E}-07$ \\
\hline Toluene & $<0.5$ & $<2.99 \mathrm{E}-07$ \\
\hline Trichloroethylene (TCE) & $<0.5$ & $<2.99 \mathrm{E}-07$ \\
\hline Tetrachloroethylene (PCE) & $<0.5$ & $<2.99 \mathrm{E}-07$ \\
\hline SVOA (all analytes) ${ }^{\mathrm{q}}$ & $<5$ & $<2.99 \mathrm{E}-6$ \\
\hline Phenol & $<5$ & $<2.99 \mathrm{E}-6$ \\
\hline PCBs (all analytes) & $<5^{\mathrm{r}}$ & $<2.99 \mathrm{E}-6$ \\
\hline Tetraphenylborate (TPB) & $<40$ & $<2.39 \mathrm{E}-05$ \\
\hline TOC & $<6.25 \mathrm{E}+02$ & $<3.73 \mathrm{E}-04$ \\
\hline $\mathrm{pH}^{\mathrm{s}}$ & NA & NA \\
\hline
\end{tabular}

\subsection{Conclusions/Recommendation}

The Savannah River National Laboratory (SRNL) has been requested to perform analyses on samples of the Defense Waste Processing Facility (DWPF) decon frit slurry (i.e., supernate samples and sump solid samples). Four 1-L liquid slurry samples were provided to SRNL by Savannah River Remediation (SRR) from the 'front-end' decon activities. Additionally, two 1-L sump solids samples were provided to SRNL for compositional and physical analysis.

In this report, the physical and chemical characterization results of the slurry solids and sump solids are reported. Crawford et al. (2010) provide the results of the supernate analysis. The results of the sump solids are reported on a mass basis given the samples were essentially dry upon receipt. The results of the slurry solids were converted to a volume basis given approximately 2.4 grams of slurry solids were obtained from the $\sim 4$ liters of liquid slurry sample.

\footnotetext{
${ }^{\mathrm{q}}$ Diethylphthalate was detected at $91 \mu \mathrm{g} / \mathrm{g}$ in SLUSOL-1. Given phthalate was not detected in the supernate (Crawford et al. 2010) nor in the sump solids (see Table 5 of this report), it is highly probable that this species was a contaminant associated with sampling or storage.

${ }^{\mathrm{r}} \mathrm{AD}$ reported the $\mathrm{PCB}$ detection limit for the slurry solids as $5 \mu \mathrm{g} / \mathrm{g}$ which is a higher detection limit than that associated with the sump solids due to the limited amount of slurry solids available for analysis.

${ }^{\mathrm{s}} \mathrm{pH}$ for the slurry solids is not applicable.
} 
Although there were slight differences in the analytical results between the sump solids and slurry solids the following general summary statements can be made. Slight differences in the results are also captured for specific analysis.

\section{Physical characterization}

$>\mathrm{SEM} / \mathrm{EDS}$ analysis suggested that the samples were enriched in $\mathrm{Li}$ and $\mathrm{Si}$ (B and $\mathrm{Na}$ not detectable using the current EDS system) which is consistent with two of the four principle oxides of Frit $418\left(\mathrm{~B}_{2} \mathrm{O}_{3}, \mathrm{Na}_{2} \mathrm{O}, \mathrm{Li}_{2} \mathrm{O}\right.$ and $\left.\mathrm{SiO}_{2}\right)$.

$>\mathrm{SEM} / \mathrm{EDS}$ analysis also identified impurities which were elementally consistent with stainless steel (i.e., $\mathrm{Fe}, \mathrm{Ni}, \mathrm{Cr}$ contamination).

$>$ XRD results indicated that the sump solids samples were amorphous which is consistent with XRD results expected for a Frit 418 based sample.

$>$ For the sump solids, SEM/EDS analysis indicated that the particle size of the sump solids were consistent with that of an as received Frit 418 sample from a current DWPF vendor.

$>$ For the slurry solids, SEM/EDS analysis indicated that the particle size range of the slurry solids was much broader than compared to the sump solids. More specifically, there were significantly more fines in the slurry solids as compared to the sump solids.

$>$ PSD results indicated that $>99 \%$ of both the sump and slurry solids were less than 350 microns. The PSD results also supported SEM/EDS analysis that there were significantly more fines in the slurry solids as compared to the sump solids.

\section{Weight Percent Solids}

Based on the measured supernate density and mass of insoluble solids (2.388 grams) filtered from the four liters of liquid slurry samples, the weight percent insoluble solids was estimated to be $0.060 \mathrm{wt} \%$. This level of insoluble solids is higher than the ETP WAC limit of $100 \mathrm{mg} / \mathrm{L}$, or $0.01 \mathrm{wt} \%$ which suggests a separation technology of some type would be required.

\section{Chemical Analysis}

$>$ Elemental results from ICP-ES analysis indicated that the sump solids and slurry were very consistent with the nominal composition of Frit 418. There were other elements identified by ICP analysis which were either consistent with the presence of stainless steel (as identified by SEM/EDS analysis) or impurities that have been observed in "as received" Frit 418 from the vendor.

$>$ IC anion analysis of the sump solids and slurry solids indicated all of the species were less than detection limits.

$>$ Radionuclide analysis of the sump solids also indicated that most of the analytes were either at or below the detection limits.

$>$ Organic analysis of the sump solids and slurry solids indicated all of the species were less than detection limits.

It should be noted that the results of this study may not be representative of future decon frit solutions or sump/slurry solids samples. Therefore, future DWPF decisions regarding the possible disposal pathways for either the aqueous or solid portions of the Decon Frit system need to factor in the potential differences. More specifically, introduction of a different frit or changes to other DWPF flowsheet unit operations (e.g., different sludge batch or coupling with other process streams) may impact not only the results but also the conclusions regarding acceptability with respect to the ETF WAC limits or other alternative disposal options. 


\subsection{References}

Best, DR. 2010. DWPF Frit 418 - Ferro Corp.- Lot 67 PO\#KR80146H, SRNL-L3100-201000155, Savannah River National Laboratory, Aiken, South Carolina.

Crawford, CL and DK Peeler. 2010. Task Technical and Quality Assurance Plan for DWPF Water Separation from Decon Frit: Analysis of Spent Decon Frit Slurry Sample, SRNL-RP-201000497, Revision 1, Savannah River National Laboratory, Aiken, South Carolina.

Crawford, CL, DK Peeler, and JH Gillam. 2010. DWPF Decon Frit: Supernate Analysis, SRNL-STI-2010-00536, Revision 0, Savannah River National Laboratory, Aiken, South Carolina.

Hutsell. 2010. DWPF Water Separation from Decon Frit: Analysis of Spent Decon Frit Slurry Sample, DJ Hutsell and JM Bricker, HLW-DWPF-TTR-2010-0005, Revision 0, January 2010.

Martin. 2009. F/H Effluent Treatment Project Waste Acceptance Criteria, DJ Martin, Effluent Treatment Project Engineering, X-SD-H-0009, Revision 4, Effective Date: April 2, 2009. 


\section{Distribution:}
A.B. Barnes, 999-W
D.A. Crowley, 773-43A
S.D. Fink, 773-A
B.J. Giddings, 786-5A
C.C. Herman, 999-W
S.L. Marra, 773-A
F.M. Pennebaker, 773-42A
J.W. Amoroso, 999-W
C.J. Bannochie, 773-42
N.E. Bibler, 773-A
A.L. Billings, 999-W
C.L. Crawford, 773-42A
D.R. Click, 773-A
A.I. Fernandez, 999-W
K.M. Fox, 999-W
J.M. Gillam, 766-H
B.A. Hamm, 766-H
J.F. Iaukea, 704-30S
C.M. Janzten, 773-A
F.C. Johnson, 999-W
D.C. Koopman, 999-W
D.P. Lambert, 999-W
R.T. McNew, 704-27S
J.D. Newell, 999-W
J.E. Occhipinti, 704-S
J.M Pareizs, 773-A

D.K. Peeler, 999-W

B.R Pickenheim, 999-W

J.W. Ray, 704-S

S.H. Reboul, 773-A

H.B. Shah, 766-H

D.C. Sherburne, 704-S

A.V. Staub, 704-Z

M.E. Stone, 999-W

M.A. Broome, 704-29S

R.N. Hinds, 704-S

J. P. Vaughan, 773-41A

J.M. Bricker, 704-27S

D.J. Hutsell, 704-24S

T.L. Fellinger, 704-26S

E.W. Holtzscheiter, 704-15S

M.T. Keefer, 766-H 